\title{
Current understanding of substrate specificity and regioselectivity of LPMOs
}

\author{
Xiaoli Zhou and Honghui Zhu* (B)
}

\begin{abstract}
Renewable biomass such as cellulose and chitin are the most abundant sustainable sources of energy and materials. However, due to the low degradation efficiency of these recalcitrant substrates by conventional hydrolases, these biomass resources cannot be utilized efficiently. In 2010, the discovery of lytic polysaccharide monooxygenases (LPMOs) led to a major breakthrough. Currently, LPMOs are distributed in 7 families in CAZy database, including AA9-11 and AA13-16, with different species origins, substrate specificity and oxidative regioselectivity. Effective application of LPMOs in the biotransformation of biomass resources needs the elucidation of the molecular basis of their function. Since the discovery of LPMOs, great advances have been made in the study of their substrate specificity and regioselectivity, as well as their structural basis, which will be reviewed below.
\end{abstract}

Keywords: Lytic polysaccharide monooxygenase, LPMO, Substrate specificity, Regioselectivity

\section{Introduction}

Biocatalytic degradation of renewable biomass resources is a potential way to address energy and environmental crises. Despite the abundance, the crystalline structure of cellulose and chitin hinders the accessibility of hydrolases, and thus the effective saccharification by traditional glycoside hydrolase systems. In 1950, Reese et al. postulated that the process of cellulolytic organisms degrading cellulose involves two steps (Reese et al. 1950). Firstly, the 'C1' degrades native cellulose into shorter linear polyanhydroglucose chains, which are then hydrolyzed by Cx into soluble, small molecules. In 1974, Eriksson et al. reported the presence of an oxidase in the extracellular enzyme system of Sporotrichum pulverulentum, which boosted the degradation of cellulose by the mixture of endo- and exo-glucanases (Eriksson et al. 1974). However, this oxidase has not been clearly characterized for a long time.

\footnotetext{
*Correspondence: zhuhh@gdim.cn

State Key Laboratory of Applied Microbiology Southern China,

Guangdong Provincial Key Laboratory of Microbial Culture Collection and Application, Guangdong Microbial Culture Collection Center

(GDMCC), Guangdong Institute of Microbiology, Guangdong Academy of Sciences, Guangzhou 510070, China
}

The first structure of Cel61B (a member of GH61 family) was resolved in 2008, revealing its difference from other glycoside hydrolases, suggesting that it may have different enzyme activities (Karkehabadi et al. 2008). Until 2010, Vaaje-Kolstad et al. reported that the bacterial CBP21protein (a member of CBM33 family) is actually an enzyme that catalyzes oxidative depolymerization of chitin (Vaaje-Kolstad 2010). Shortly thereafter, the cellulose oxidative activities of GH61 family members were characterized (Quinlan et al. 2011). Then these $\mathrm{Cu}$ dependent enzymes were named as lytic polysaccharide monooxygenases (LPMOs), and the GH61 and CBM33 families were reclassified as AA9 (Auxiliary Activity family 9) and AA10, respectively. Currently the LPMOs are distributed in 7 Auxiliary Activity families in CAZy database (www.cazy.org), with various origins and substrate specificities: AA9s, AA11s, AA13s, AA14s and AA16s are mainly from eukaryota with cellulose-, chitin-, starch-, and xylan-active, respectively; AA10s are from bacteria, eukaryota, viruses or archaea, with cellulose- or chitinactivity; AA15s are from eukaryota (including insect) or viruses, with cellulose- or chitin-activity. The currently reported cleavage of chitin, starch and xylan substrates is $\mathrm{C} 1$-oxidized, while the cleavage of cellulosic substrates 
is C1- or C4-oxidized, or both. The information on currently characterized LPMOs are summarized in Table 1.

Despite the low sequence identities, the catalytic domains of these LPMOs share some common structural features (Fig. 1), as recently reviewed (Beeson et al. 2015; Hemsworth et al. 2013a; Span and Marletta 2015; VaajeKolstad et al. 2017). The core of the catalytic domain is a $\beta$ sandwich of seven to nine $\beta$-strands. Loops connecting these $\beta$-strands constitute the 'flat' substrate binding surface, which is believed to interact with flat surfaces of crystalline substrates. The region located between $\beta 1$ and $\beta 2$ of LPMO9 (between $\beta 1$ and $\beta 3$ of LPMO10), denoted L2, includes a variable number of loops and short helices. Some LPMOs have an insertion between $\beta 3$ and $\beta 4$ denoted L3, which interacts with L2. In AA9 and AA13 LPMOs, there are LS (loop short) on the opposite side of L2. Besides, AA9 members have a long C-terminal loop, termed LC. As discussed below, the variable length and amino acid constitution of these loops might contribute to the substrate specificity and regioselectivity. The $\mathrm{N}$-terminal histidine and a second conserved histidine coordinate a copper ion, forming the 'histidine brace.' The $\mathrm{N}$-terminal histidine of some fungal LPMOs is methylated at the Nع2, and the significance of this methylation is unclear.

Studies have shown that adding LPMOs to cellulase cocktails can improve the degradation efficiency of cellulose biomass and reduce the required enzyme amount (de Gouvea et al. 2019; Dimarogona et al. 2013; Harris et al. 2010; Hemsworth et al. 2015; Zhang et al. 2019). It is speculated that this synergy is due to the oxidative cleavage of polysaccharide crystalline regions by LPMOs, which provides more accessible sites for glycoside hydrolases (Fig. 2). Further elucidating the biological functions and catalytic mechanisms of these enzymes will bring more exciting possibilities for their application in the utilization of renewable biomass resources. The catalytic mechanism of LPMOs has been in scientific debate. One view is that, the catalytic center $\mathrm{Cu}$ (II) is activated by reduction into $\mathrm{Cu}$ (I) by two external electrons (Kjaergaard et al. 2014; Kracher et al. 2016). The $\mathrm{Cu}$ (I) activates dioxygen, leading to hydrogen abstraction from one of the carbons in the scissile glycoside bond. Then the hydroxylation of the resulting substrate radical leads to bond cleavage via an elimination reaction. In other studies, however, it has been proposed that, instead of dioxygen, $\mathrm{H}_{2} \mathrm{O}_{2}$ is the preferred co-substrate for LPMOs, in a peroxygenase reaction where a single priming reduction to $\mathrm{Cu}(\mathrm{I})$ is needed (Bissaro et al. 2017). The catalytic mechanism of LPMOs has been extensively reviewed (Forsberg 2019; Tandrup et al. 2018; Walton and Davies 2016) and not discussed in depth here. The focus of this review is to give an insight into the current understanding of the substrate specificity, oxidation regioselectivity and their structural basis of LPMOs.

\section{Substrate specificity}

AA9 (former GH61) and AA10 (former CBM33) were originally found to act on crystalline cellulose and chitin substrates, respectively. As more related proteins are characterized, the broad substrate spectrum of LPMO superfamily is revealed. Besides insoluble substrates (such as cellulose, chitin, starch and xylan), the soluble oligosaccharides like xyloglucan, glucomannan and $\beta$-( $1 \rightarrow 3),(1 \rightarrow 4)$-D-glucan have been found to be oxidized by some LPMOs (Isaksen et al. 2014; Kojima et al. 2016). Biochemical characterization and structural studies, especially the complex structures of LPMOs and soluble oligosaccharide substrates, provide us much for in-depth understanding of LPMOs (Frandsen et al. 2016; Simmons et al. 2017). Detailed sequence and structure comparisons have revealed that the substrate binding surfaces of LPMOs with different substrate specificities have diverse characteristics in terms of amino acid composition and topological features. Since the L2, L3, LS and LC loops constitute the majority of the substrate binding surface, and their amino acids composition are highly variable, these loops are believed to affect substrate recognition and specificity.

\section{Amino acids composition on the substrate binding surface}

There are usually several aromatic amino acids on the substrate binding surface loops of LPMO9s (Fig. 3a, b). From structural studies and MD simulations, it was found that the spatial distribution of these aromatic amino acids facilitates stacking interactions with the sugar units of cellulose substrates, although the enzymes may bind to the surface of the cellulose fibers in different directions (Liu et al. 2018; Wu et al. 2013). In Wu's study, 100 ns MD simulations of PchGH61D on cellulose showed that the three tyrosines on substrate binding surface tightly bonded with polysaccharide chains in the substrate (the interaction energies were $-10.86 \mathrm{kcal} /$ mol for $\mathrm{Y} 28,-10.17 \mathrm{kcal} / \mathrm{mol}$ for $\mathrm{Y} 75$ and $-9.5 \mathrm{kcal} /$ mol for Y198, respectively) and are the main contributors to substrate binding. While LPMO10s generally only have one aromatic amino acid involved in substrate binding, LPMO11s and LPMO13s do not even have aromatic amino acids on substrate binding surface (Fig. 3a), and their polar amino acids are more abundant, possibly binding to substrates by polar interactions (Forsberg et al. 2014a; Hemsworth et al. 2014). Structural studies and site-directed mutagenesis revealed that binding of CBP21 to chitin is mediated primarily by conserved, solventexposed, hydrophilic residues, which arranged in a patch on the substrate binding surface (Aachmann et al. 2012; 


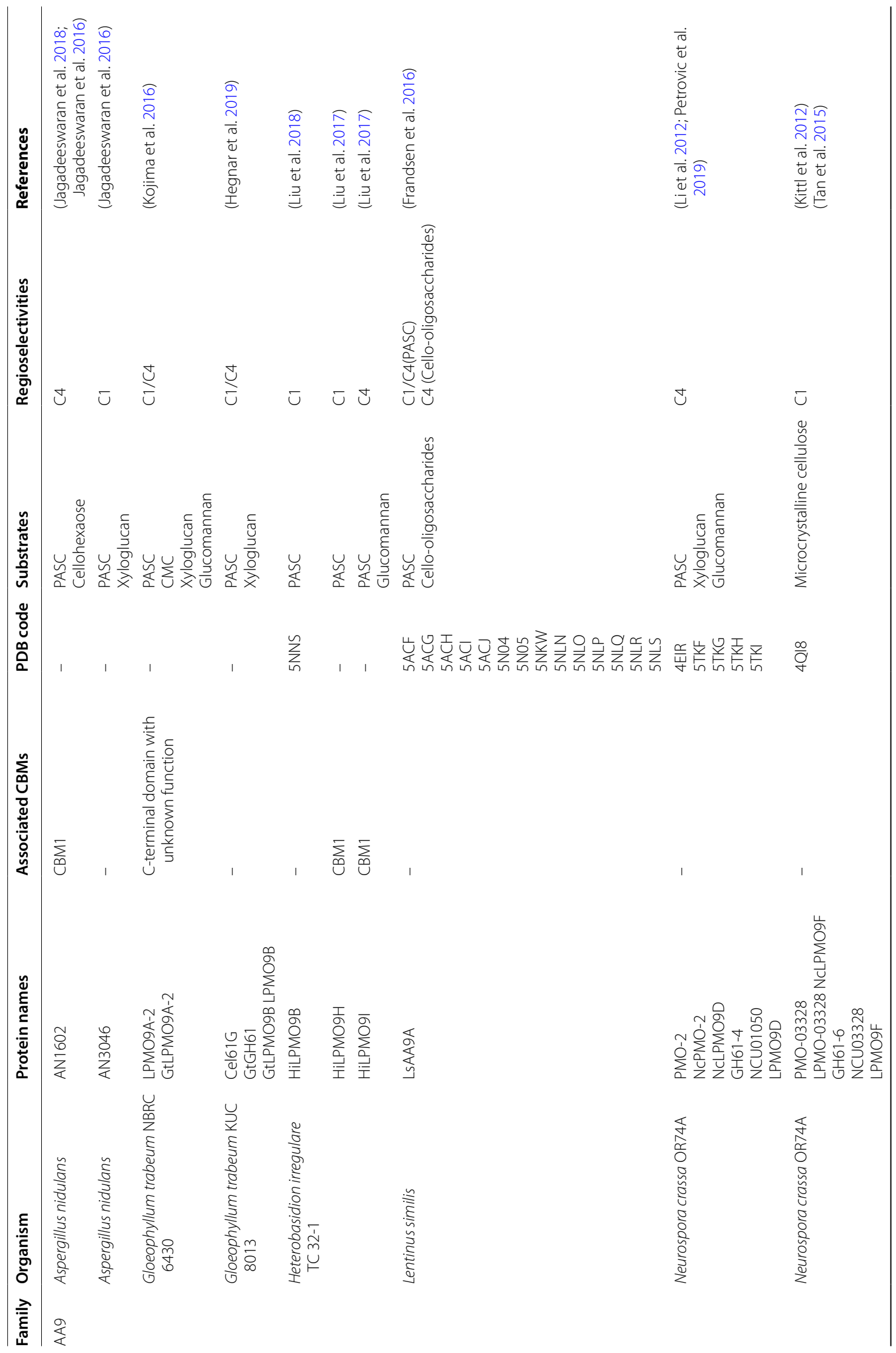




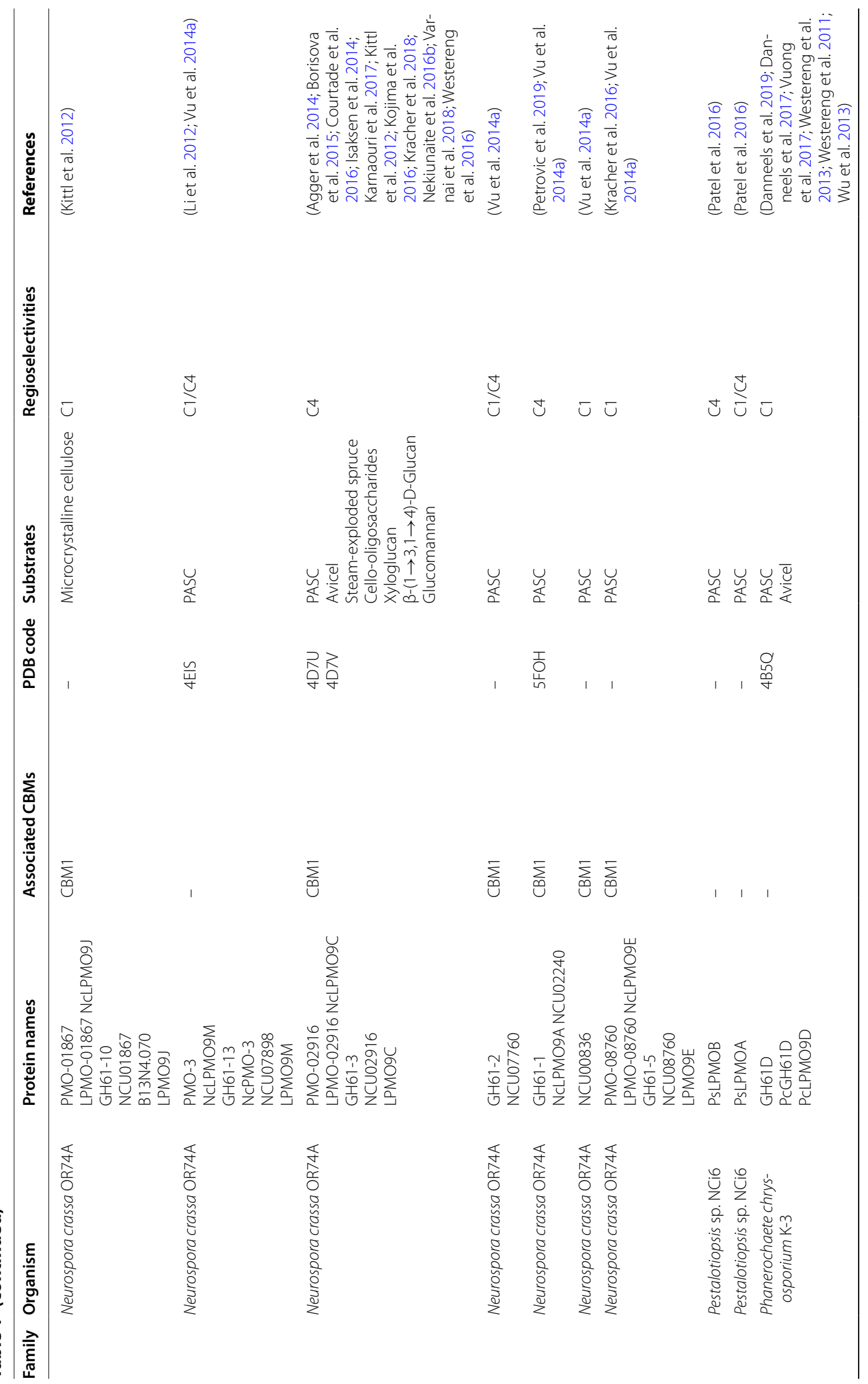




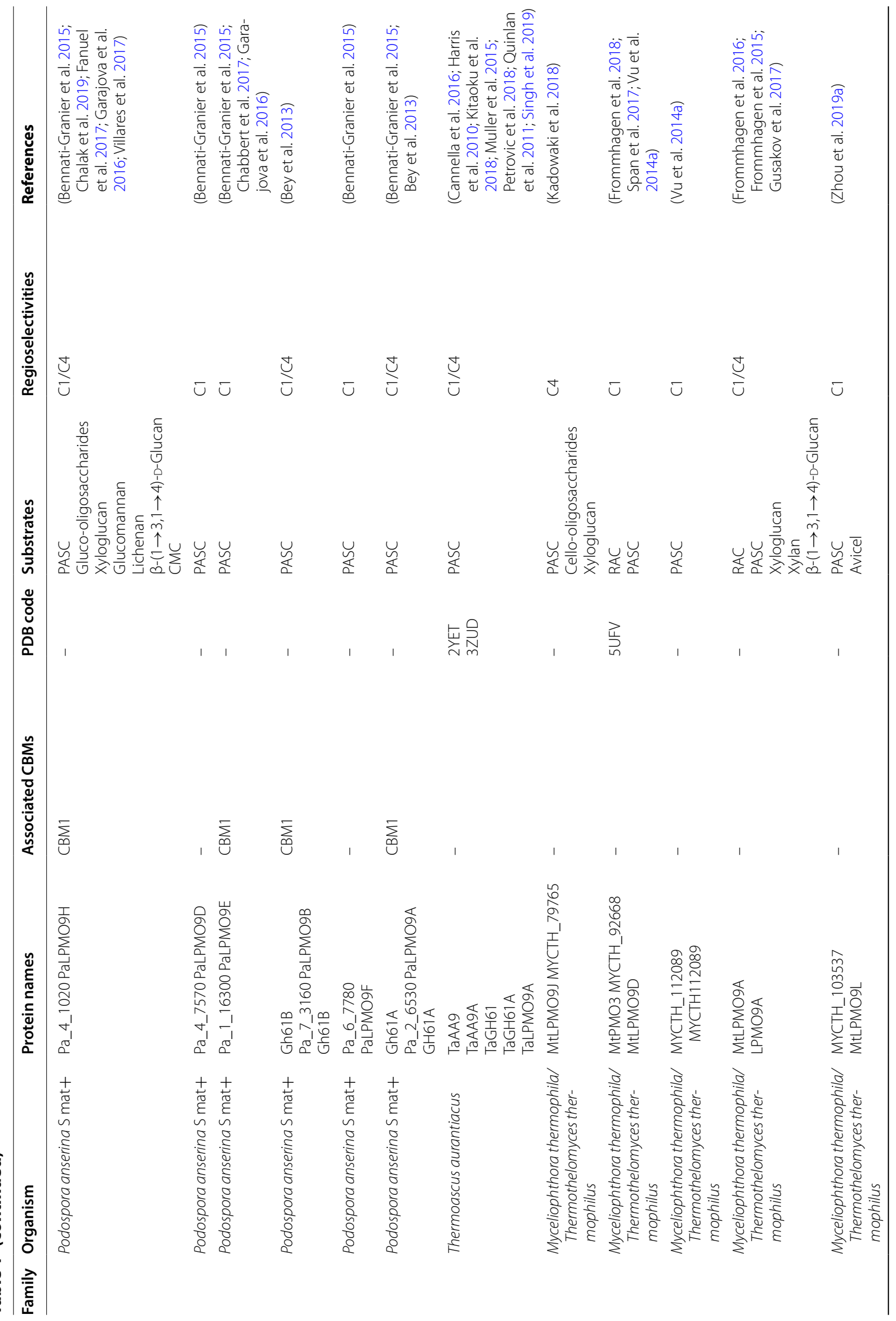




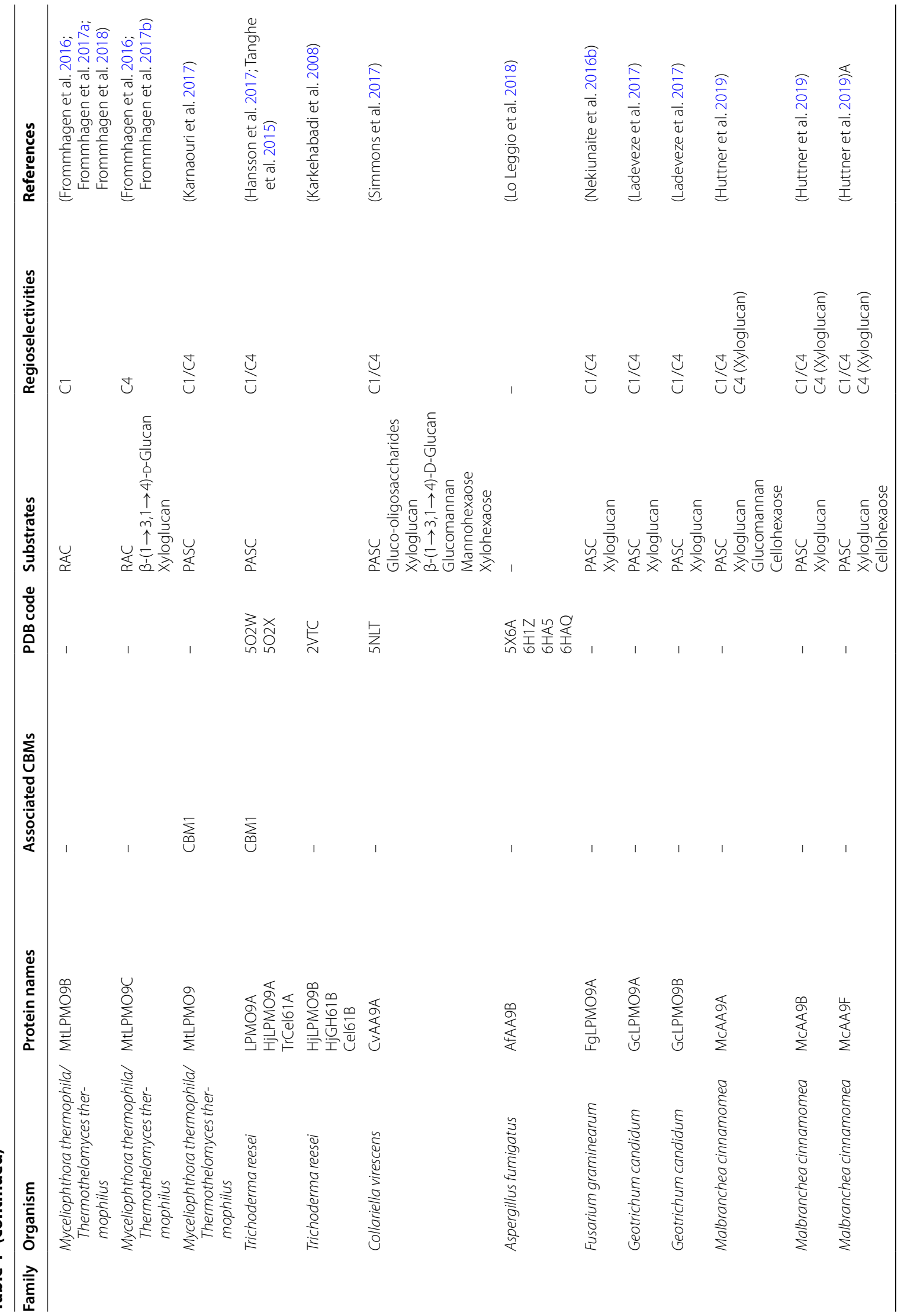




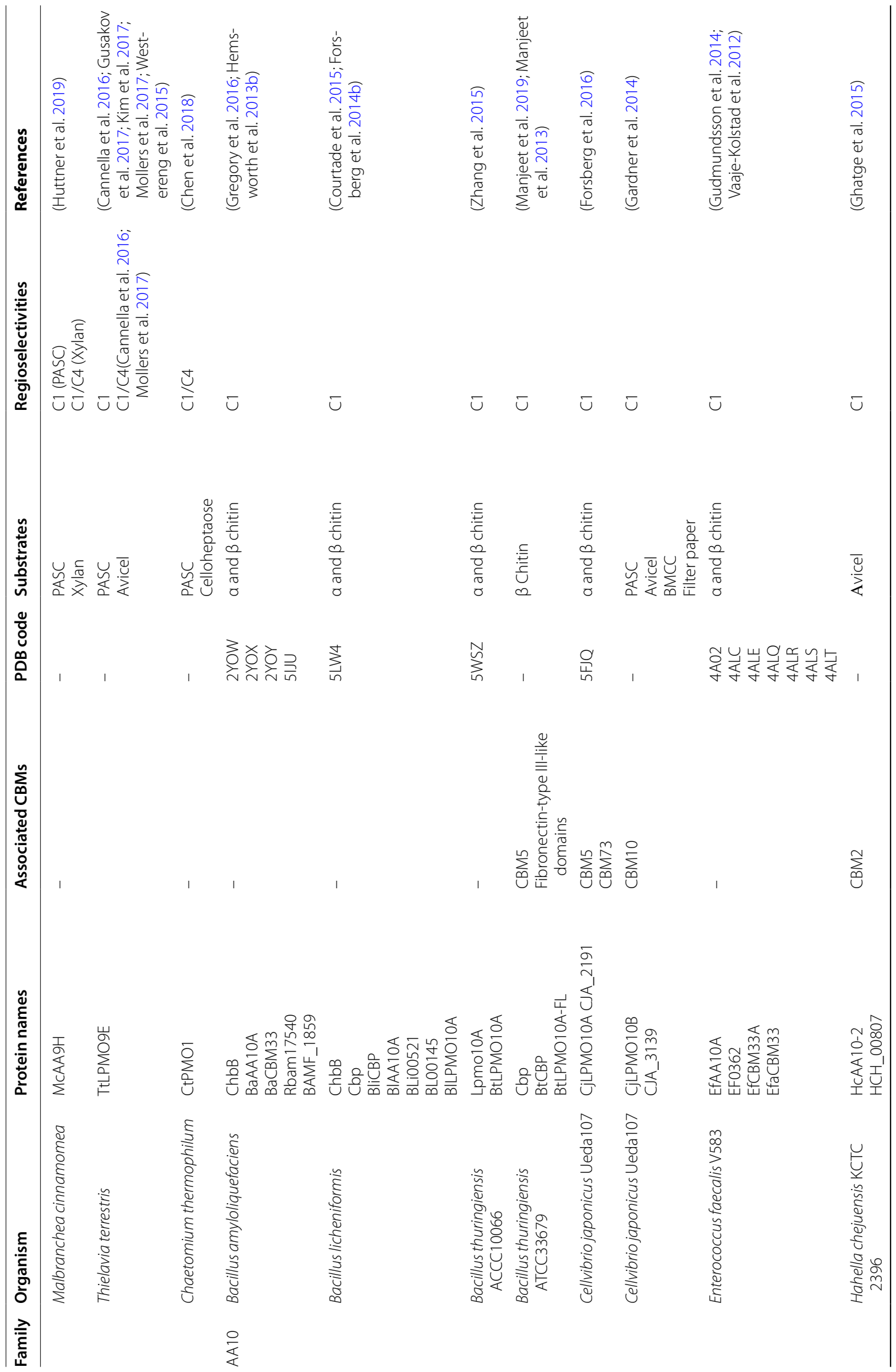




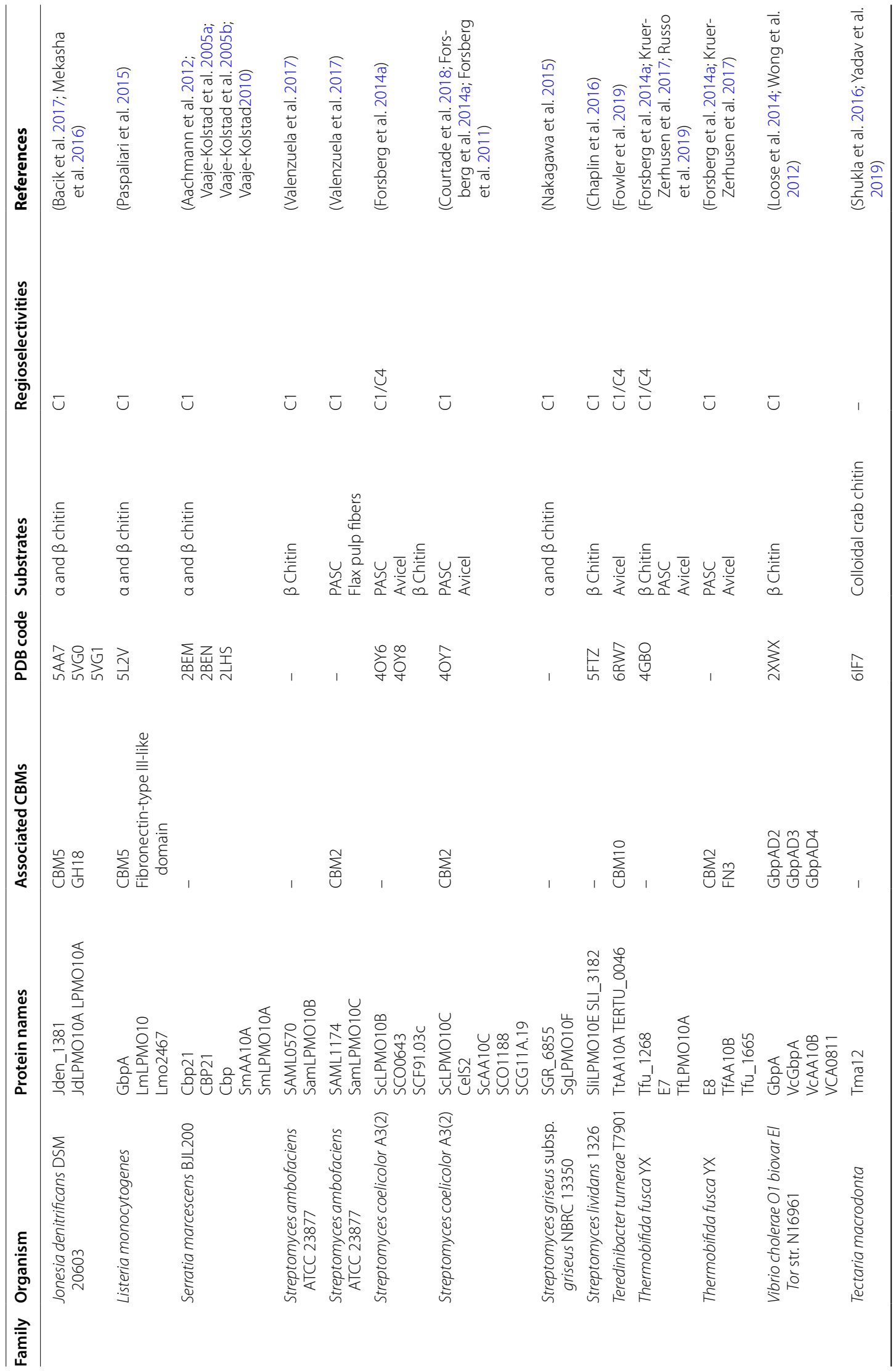




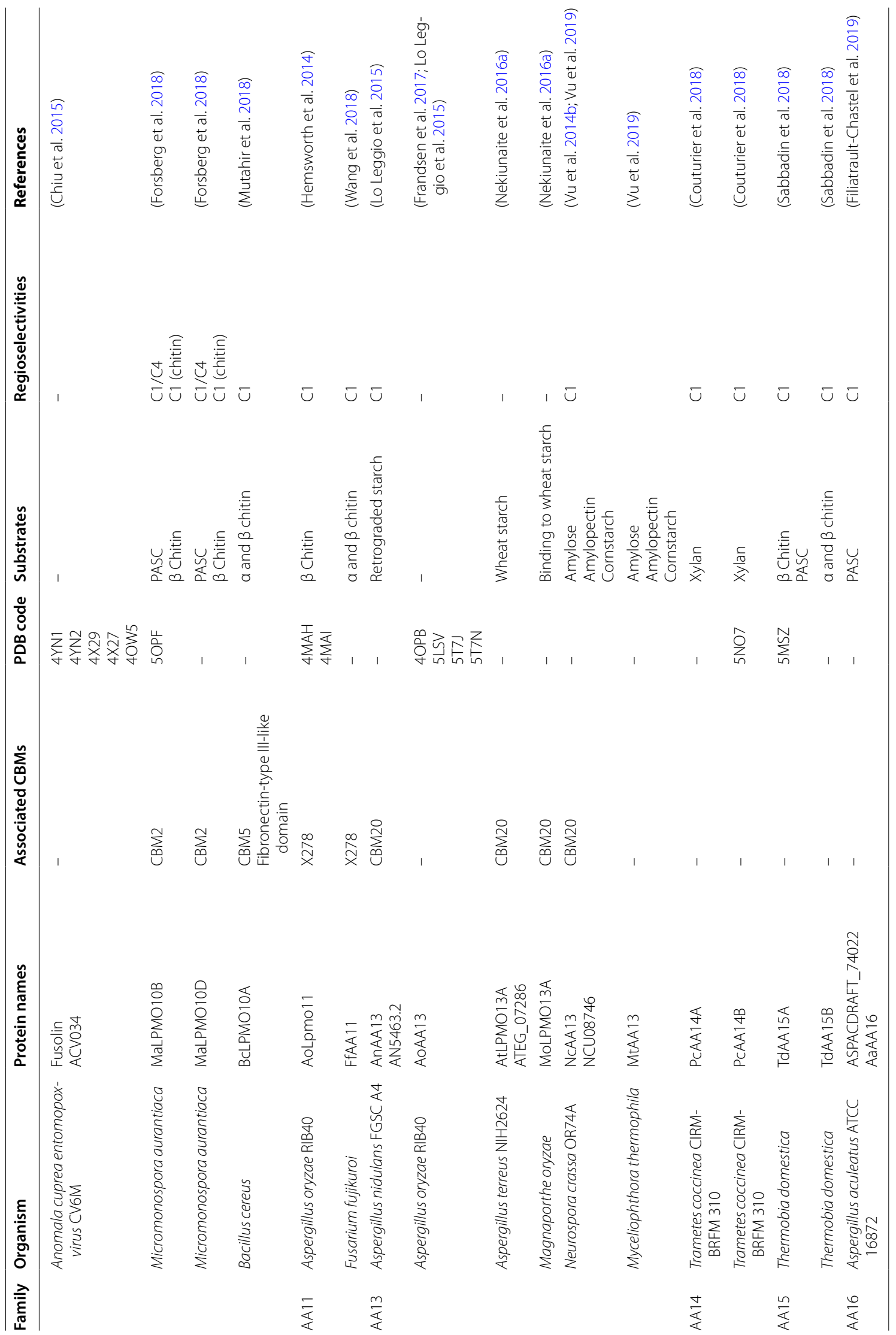




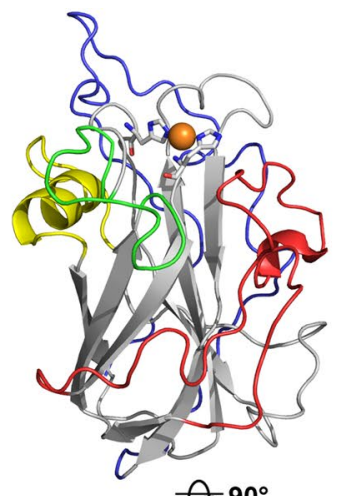

丹 $90^{\circ}$

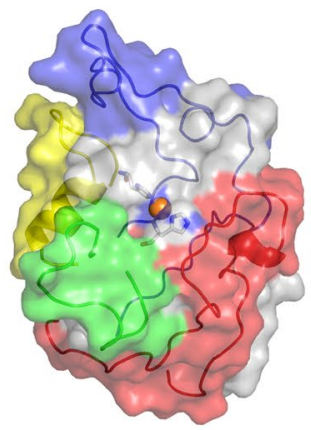

AA9

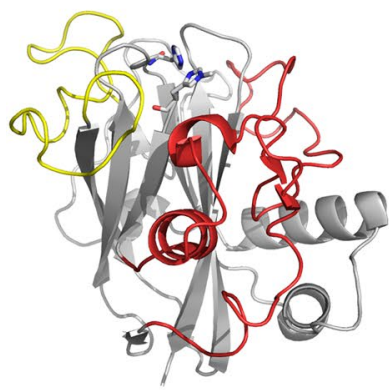

ศि $90^{\circ}$

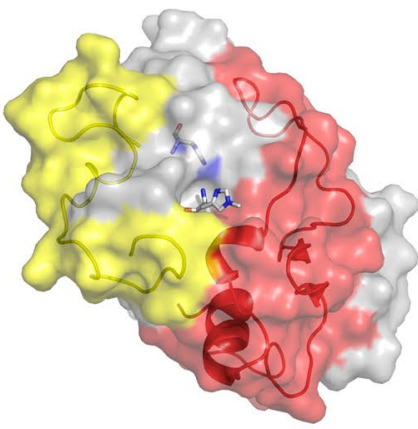

AA13
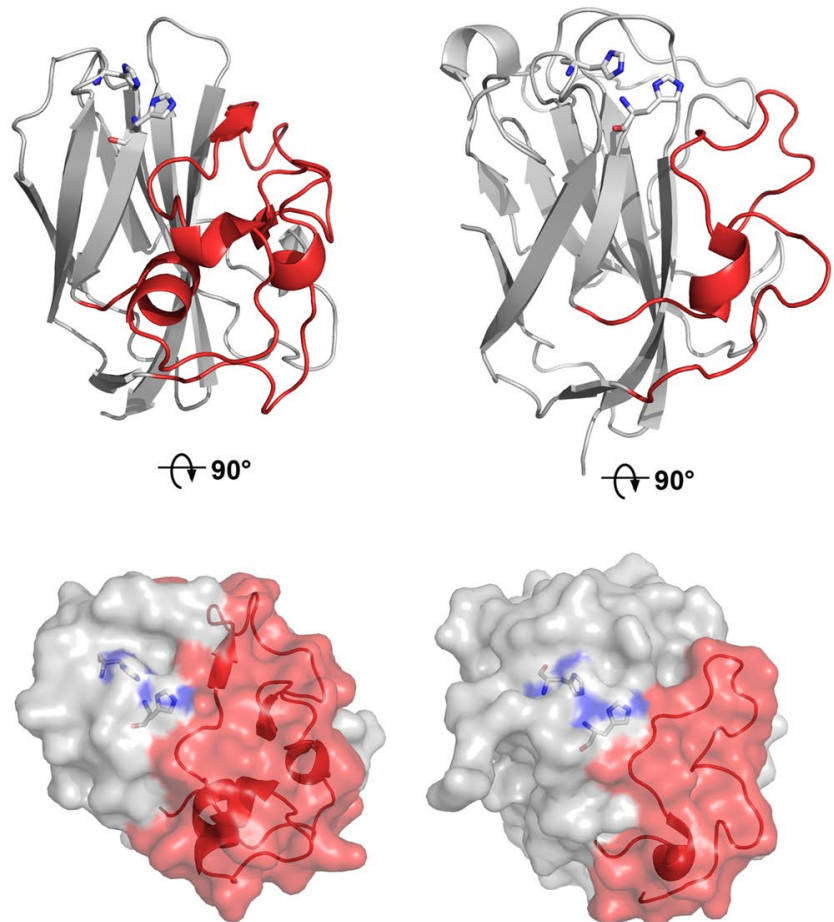

AA10

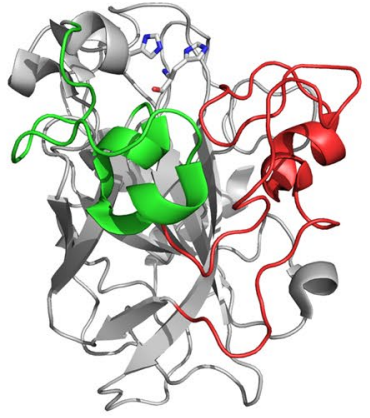

ศी $90^{\circ}$

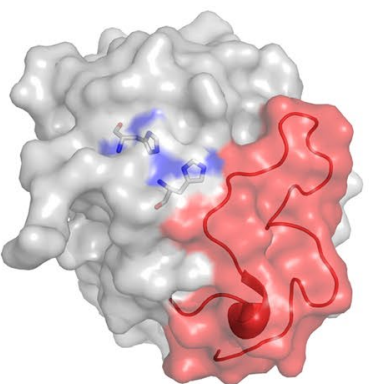

AA11
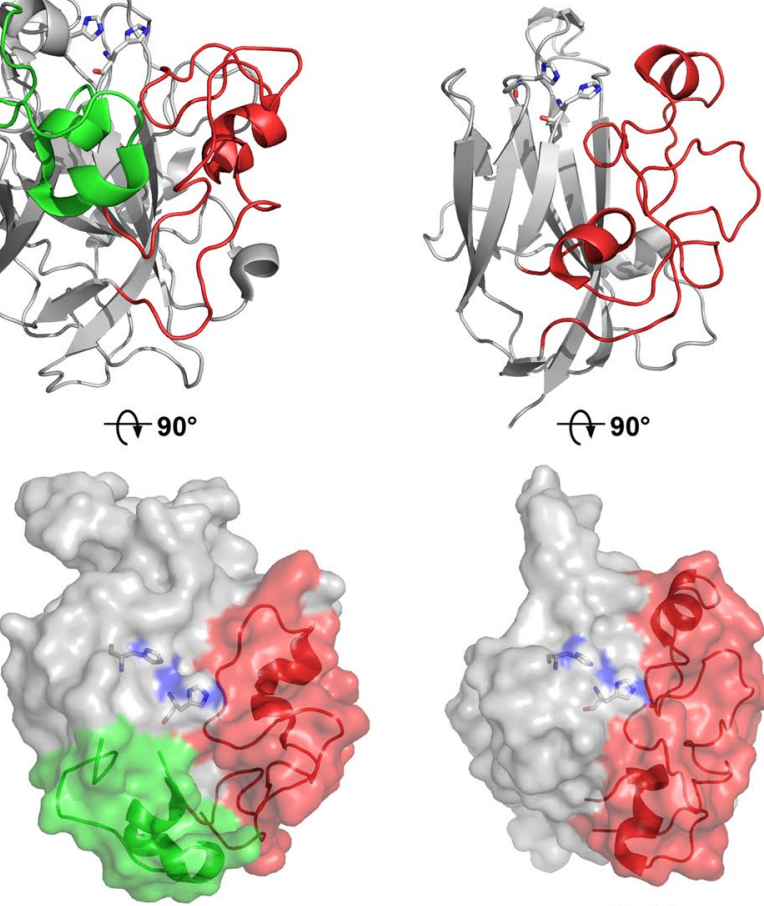

AA14

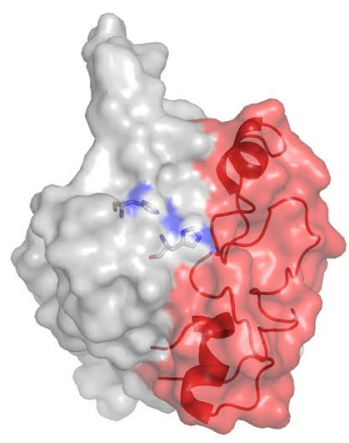

AA15

Fig. 1 The overall structures and substrate binding surfaces of LPMOs. The loop regions are colored in red (L2), green (L3), yellow (LS) and blue (LC). The catalytic center histidines are shown in sticks. The structures representing different families are: NcLPMO9C (PDB ID 4d7u) (Borisova et al. 2015), CBP21 (PDB ID 2bem) (Vaaje-Kolstad et al. 2005b), AoLPMO11 (PDB ID 4mah) (Hemsworth et al. 2014), AoAA13 (PDB ID 4OPB) (Lo Leggio et al. 2015), PcAA14B (PDB ID 5no7) (Couturier et al. 2018), TdAA15A (PDB ID 5msz) (Sabbadin et al. 2018) 


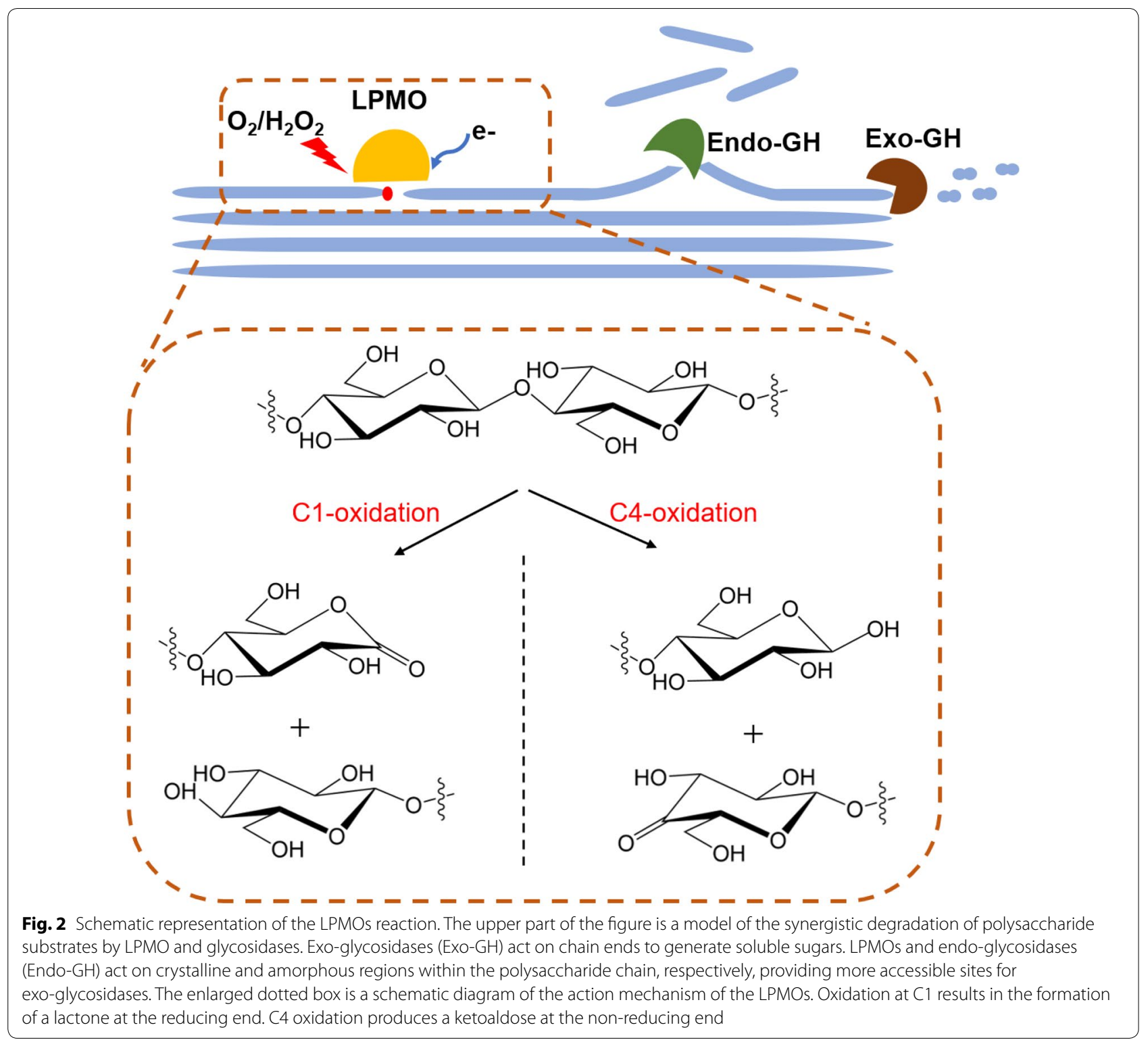

Vaaje-Kolstad et al. 2005b). MD simulations of CBP21 on crystalline chitin substrates have also shown that although the only tyrosine Y54 on the substrate binding surface is a key factor, the hydrogen bonding formed between substrate and the residues E55, T111, H114, Q57, and D182 was very important for substrate binding (Bissaro et al. 2018).

Within the AA10 family, the amino acid composition of the substrate-binding surface of different substrate-specific LPMOs is also diverse. The Gln-Thr pair (Q78 and T133 in CjLPMO10A) is presumed to be a determinant of chitin activity, since it is conserved in chitin-active LPMO10s, whereas in cellulose-active LPMO10s, the corresponding sites are Phe and Trp
(Forsberg et al. 2016). Li et al. suggested that, compared with chitin-active SmAA10A, an insertion in the cellulose-active ScAA10C that contains four aromatic residues could account for cellulose specificity (Li et al. 2012). In previous work, we found a motif on L2 with different amino acid composition in different substratespecific LPMO10s (Fig. 3c) (Zhou et al. 2019b). In cellulose-active LPMO10s, this motif mainly consists of non-polar amino acids (Y[W]NWF[N]G[A]V[N]L[Y]). While in chitin-active LPMO10s, this motif mainly consists of polar amino acids (Y[W]EPQSVE). We speculated that the different amino acid composition of this motif may lead to differences in substrate binding surface electrostatic potential, which in turn affects 


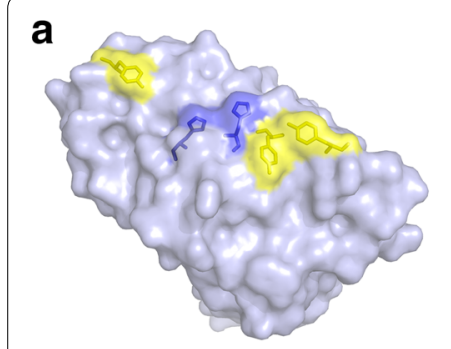

HiLPMO9B

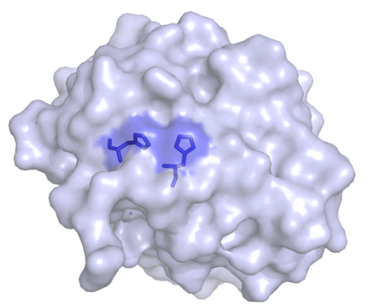

AoLPM011

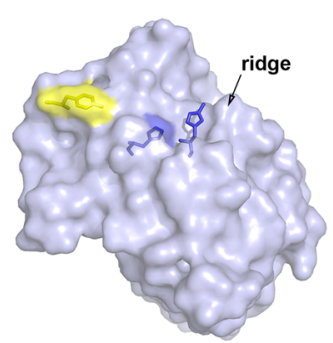

LsAA9A

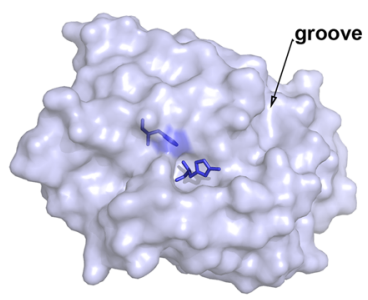

AoAA13

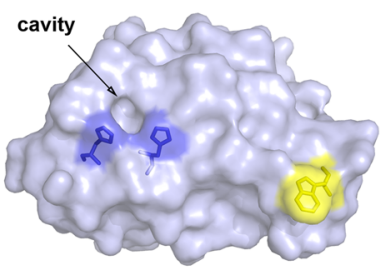

BaAA10A

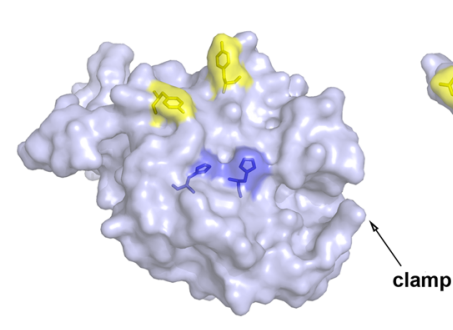

PcAA14A

30

т elee

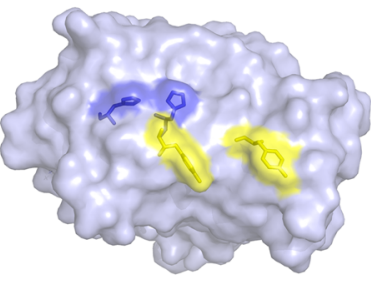

TtAA10A

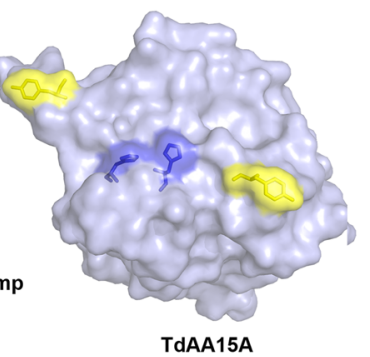

C

cellulose-active

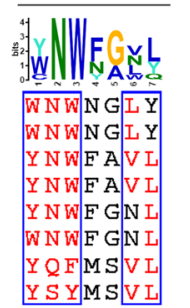

chitin-active

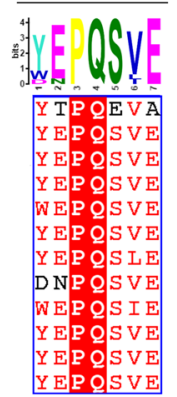

Fig. 3 The amino acid composition and topological features of substrate binding surfaces. a Substrate binding surfaces of LPMOs. The catalytic center histidines are shown in blue sticks. The aromatic amino acids on substrate binding surfaces are shown in yellow sticks. $\mathbf{b}$ Multiple sequence alignments of structurally characterized LPMO9s and LPMO10s. The aromatic amino acids on L2 are highlighted in yellow background. c The different motifs on L2 of cellulose-active and chitin-active LPMO10s

substrate specificity. Jensen et al. constructed a mutation library of five sites on the substrate binding surface of ScLPMO10C, three of which are located in this motif region (Y79, N80, F82), and the other two are located in the adjacent loops (Y111, W141). Substrate specificity of the mutant M18 (Y79/N80D/F82A/Y111F/W141Q) significantly changed from wild-type cellulose-preference to chitin-preference, demonstrating the role of these residues in substrate specificity (Jensen et al. 2019).

The complex structures of the LsAA9A and soluble oligosaccharide substrates showed that in addition to the Y203 stacking, the hydrogen bond network formed between the +2 subsite and the polar residues (N28, H66 and N67) plays an important role in substrate binding, and this may be a determinant of soluble oligosaccharide 
activity, as sequence and structure alignments found that there is no corresponding residue forming a hydrogen bond network in LPMOs that can only act on crystalline substrates (Frandsen et al. 2016).

\section{The topological features of substrate binding surface}

The crystal structure of BaAA10A shows a cavity near the catalytic $\mathrm{Cu}$ center, and the authors speculated that it is for dioxygen binding (Fig. 3a) (Hemsworth et al. 2013b). Shortly thereafter, through structural comparisons, Forsberg et al. found that this cavity is absent in the celluloseactive LPMO10s (Forsberg et al. 2014a). Therefore, the cavity was presumed to accommodate $\mathrm{N}$-acetyl group of chitin substrates, and may be a structural feature that determines substrate specificity. However, one exception is the chitin-active CjLPMO10A, which shows similar features to cellulose-active LPMO10s without this cavity (Forsberg et al. 2016).

LPMOs that can act on oligosaccharides, such as LsAA9A, NcLPMO9C and NcLPMO9D, have a more contoured substrate binding surface than LPMOs that can only act on crystalline substrates (Borisova et al. 2015; Frandsen et al. 2016; Li et al. 2012). The ridge near substrate binding subsites +1 and +2 was proposed to allow LPMOs binding to more contoured substrates such as oligosaccharides (Fig. 3a).

In AoAA13, the surface loops (the long loop preceding $\beta 2$, the loop between $\beta 2$ and $\beta 3$, the long loop preceding $\beta 4$ and the loop between $\beta 5$ and $\beta 6$ ) form a shallow groove, crossing the copper active site (Fig. 3a) (Lo Leggio et al. 2015). It was speculated that, compared with the flatter substrate binding surface of LPMO9s, which is more suitable for the binding of flatter crystalline cellulose substrates, the groove on the surface of AoAA13 might be more suitable for the binding of the contoured surface of resistant starch. It is worth noting that no crystal structures of the currently characterized LPMO13s have been resolved so far, and the structurally characterized AoAA13 has not been reported to have starch activity.

Similarly, the substrate binding surface of PcAA14B, an xylan-active LPMO, has a rippled shape with a clamp formed by two prominent surface loops, which are equivalent to the L2 and L3 regions of AA9 (Figs. 1 and 3a). The extended L3 loop of PcAA14B forms a protrusion through the cystines (C67-C90). Although there is no enzyme-substrate complex structure, these loops constitute a large part of the substrate binding surface, and it is speculated that this clamp is a structural feature of LPMO14s required for the xylan substrate binding (Couturier et al. 2018).

From the sequence alignment of PaLPMO9H and NcLPMO9C, it was speculated that the L3 loop, which is a common feature of these two enzymes, might be a prerequisite for xyloglucan specificity (Bennati-Granier et al. 2015). NMR (nuclear magnetic resonance) studies on enzyme-substrate interactions also showed that L3 of NCLPMO9C did participate in the binding of xyloglucan substrate (Courtade et al. 2016). However, as more LPMOs are characterized, some enzymes have been found to have xyloglucan-activity, but L3 is absent, such as GtLPMO9A-2. It was presumed that the extended L2 of the xyloglucan-active GtLPMO9A-2 compensate for the lack of L3 (Kojima et al. 2016).

\section{The appended modules}

Similar to GHs (glycoside hydrolases), a considerable part of LPMOs are modular, with domains of noncatalytic CBMs (carbohydrate-binding modules), GHs or other unknown functions appended to the catalytic domain. Domain similarity network analysis has shown the correlation between the additional domains and the substrate specificity of the full enzymes (Book et al. 2014; Zhou et al. 2019b). CBM truncation studies have been reported for both LPMO9s and LPMO10s (Chalak et al. 2019; Courtade et al. 2018; Crouch et al. 2016; Forsberg et al. 2016; Laurent et al. 2019). Comparison of the performance of LPMOs with and without CBMs have shown that, deletion of CBMs reduced LPMO's binding capacity to crystalline substrates, especially at low substrate concentrations. Therefore, CBMs may affect substrate specificity through promoting the binding of LPMOs to the appropriate substrates.

\section{Oxidative regioselectivity}

LPMO9s have been shown to oxidize either the C1, C4 or both the $\mathrm{C} 1$ and $\mathrm{C} 4$ carbon of the scissile bond of cellulose substrates. According to the oxidative regioselectivity, LPMO9s have been classified into three types: $\mathrm{PMO} 1 \mathrm{~s}$ are the strict $\mathrm{C} 1$-oxidizers; $\mathrm{PMO} 2 \mathrm{~s}$ are the strict C4-oxidizers; PMO3s are the mixed C1/ C4-oxidizers; and a subtype of PMO3, PMO3*s, are the C1-oxidizers ( $\mathrm{Vu}$ et al. 2014a). Cellulose-active LPMO10s are strict C1-oxidizers or mixed C1/C4-oxidizers, whereas no strict C4-oxidizing LPMO10 has been reported. LPMOs acting on chitin (LPMO10s, 11s and 15s), starch (LPMO13s) and xylan (LPMO14s) have only been shown to oxidize the C1-carbon. It is speculated that the oxidative regioselectivity may be determined by the precise positioning of the enzyme on the substrates, so factors that affect the relative position of the enzyme's active center $\mathrm{Cu}$ and the $\mathrm{C} 1$ or $\mathrm{C} 4$ carbon of the scissile glycosidic bond may affect regioselectivity (Fig. 4). 


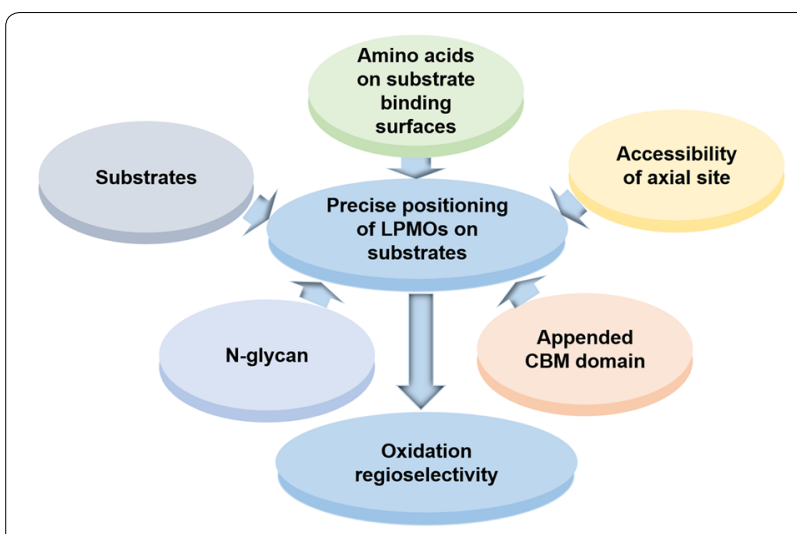

Fig. 4 Factors influencing oxidative regioselectivity

\section{Amino acid composition and arrangement on substrate binding surface}

Due to the contribution of L2 to the substrate binding surface and the diversity of its amino acid composition, many studies on the regioselectivity of LPMOs have focused on this region. By sequence alignment, $\mathrm{Vu}$ et al. found that PMO3s had a 12-amino acid insertion on L2, including a conserved tyrosine, compared to other subgroups of LPMO9s. Deletion of this sequence caused the loss of C4-oxidizing function of NCU07760, indicating the importance of this sequence for $\mathrm{C} 4$ regioselectivity of PMO3. However, although the conserved tyrosine in this insertion is a feature of PMO3, mutation of this residue into glycine did not change the regioselectivity of NCU07760 (Vu et al. 2014a).

Sequence and structural information show that the number and distribution of aromatic residues on the surfaces of LPMOs are different. Therefore, it is speculated that LPMOs may bind to the substrates in different directions, resulting in different regioselectivity ( $\mathrm{Li}$ et al. 2012). Recently, Danneels et al. studied the oxidative regioselectivity of LPMO9s in detail (Danneels et al. 2019). One part of the research was the mutation of aromatic amino acids on the substrate binding surfaces of PCLPMO9D, ScLPMO9C and HjLPMO9A. They found that the properties of these aromatic amino acids affect C1/C4-oxidation ratios. In another work, Liu et al. used molecular dynamics simulations to study the binding mode of HiLPMO9B to the substrate, and found that multiple surface-exposed hydrophobic residues, including the tyrosine on L2, are important for substrate binding in this C1-specific LPMOs. Besides, acidic amino acids on L2 and LC participate in substrate binding. In both the two binding modes obtained with different binding directions, the catalytic center $\mathrm{Cu}$ is more biased towards the $\mathrm{C} 1$ carbon of the glycosidic bond, suggesting that the arrangement of amino acids on substrate binding surface may affect regioselectivity by affecting the relative position of the catalytic center $\mathrm{Cu}$ and the substrate (Liu et al. 2018).

Similar speculation has been made for LPMO10s. On the substrate-binding surface of chitin-active C1-specific LPMO10s, the conservative amino acids involved in the formation of hydrogen bonds with the polysaccharide substrate are arranged on opposite sides of the catalytic center $\mathrm{Cu}$, and thus direct the orientation of the substrate relative to the $\mathrm{Cu}$. This directed binding makes the enzyme prone to act on $\mathrm{C} 1$ carbon of the scissile glycosidic bond (Hemsworth et al. 2013b). Forsberg et al. mutated a subset of coevolutionary residues of C1/C4-oxidizing MaLPMO10B into the corresponding residues of $\mathrm{C} 1$-oxidizing LPMO10s, and the resulting mutants lost the C4-oxidizing activity. They found that, the residues located near the catalytic $\mathrm{Cu}$ that are involved in substrate positioning (especially the N85 of MaLPMO10B) are the major determinants of regioselectivity (Forsberg et al. 2018).

\section{Accessibility to the surface-exposed axial copper coordination site}

A conserved alanine in LPMO10s active site has been postulated to provide steric congestion at the solventfacing axial position of active center $\mathrm{Cu}$ (Hemsworth et al. 2013b). Subsequent research showed that the loop hosting this alanine adopts different conformations in $\mathrm{C} 1$ - and $\mathrm{C} 1 / \mathrm{C} 4$-oxidizers, making the solvent-facing axial position of C1/C4-specific ScLPMO10B more open than C1-specific ScLPMO10C (Forsberg et al. 2014a). Similarly, structural comparisons revealed that, strictly C1-oxidizing LPMO9s have a conserved tyrosine, preventing optimal axial access to the copper ion, whereas C4-oxidizing LPMO9s have an open access to this position. The mixed C1/C4-oxidizing LPMO9s show an intermediate situation (Borisova et al. 2015). Thus, the accessibility of surface-exposed axial position of $\mathrm{Cu}$, or the ability to bind a ligand in the axial position, could be a determinant of C4-oxidizing activity. However, recent studies suggested that, mutations affecting accessibility of this axial position did not change the regioselectivities of PcLPMO9D and MaLPMO10B (Danneels et al. 2019; Forsberg et al. 2018).

\section{The appended CBM modules}

The CBM domains seem to affect the binding of LPMOs to substrates, thereby affecting the precise positioning of the enzymes on the substrates' surfaces, that is, the relative position of $\mathrm{C} 1$ or $\mathrm{C} 4$ carbon to the catalytic center $\mathrm{Cu}$, and thus the regioselectivity of the enzymes. Removing or replacing the endogenous CBMs of LPMO9s and LPMO10s have been reported to alter the regioselectivity 
of these enzymes. For instance, deleting CBM1 of PaLP$\mathrm{MO} 9 \mathrm{H}$ significantly increased the proportion of $\mathrm{C} 1$-oxidized products (Laurent et al. 2019). Crouch et al. replaced the endogenous CBM2a domain of TbLPMO10 with the CBM10 of CjLPMO10B, and found that the ratio of non-oxidized to oxidized products of the mutant increased significantly. The authors speculated that the non-oxidized products are the oligosaccharides derived from $\mathrm{C} 1$-oxidation near the reducing end of cellulose, which may be due to the grafted CBM affecting the localization of the enzyme on the substrate (Crouch et al. 2016). But the impact of CBMs on the regioselectivity of LPMOs is also controversial, e.g., removing the CBM domains did not significantly change the regioselectivity of MaLPMO10B, NcLPMO9C and HjLPMO9A (Danneels et al. 2019; Forsberg et al. 2018; Laurent et al. 2019).

\section{$\mathrm{N}-\mathrm{Glycan}$ on substrate binding surface}

Fungal-derived LPMOs are generally glycosylated on the surface, but their function is unclear. Sequence and structural information show that C1/C4-specific LPMO9s often have an $\mathrm{N}$-glycan at the planar active surface, which is a feature different from the other two groups ( $\mathrm{Li}$ et al. 2012). Mutation studies showed that removing this $\mathrm{N}$-glycan can alter the C1/C4-oxidation ratios of HjLPMO9A. The authors suggested that this is because N-glycan affects the structural features of the substrate binding surface, which in turn affects the substrate binding and oxidative force accurate directions (Danneels et al. 2019).

\section{Structures of substrates}

The regioselectivity of LPMOs appears to be substratedependent. The most typical examples are the LPMO10s with both cellulose- and chitin-activity. They are C1/ C4-specific for cellulose oxidation and C1-specific for chitin oxidation. Recently, a multifunctional LPMO10, KpLPMO10A has been reported that besides chitin- and cellulose-activity, it can also act on xylan to produce C4-oxidized products (Correa et al. 2019). In addition, it is reported that, PaLPMO9H is C4-specific on mixedlinkage glucans, and C1/C4-specific on glucomannan (Fanuel et al. 2017). LsAA9A and CvAA9A are reported to be C4-specific for shorter oligosaccharides and C1/ C4-specific for longer polysaccharides (Simmons et al. 2017).

\section{Conclusions}

Elucidating the molecular basis of substrate specificity and oxidative regioselectivity of LPMOs will be more helpful for their application in the biotransformation of renewable biomass. Researches indicate that the substrate binding and regioselectivity of LPMOs are precisely regulated. This precise regulation is based on the complex synergistic modules and amino acid networks that evolved from interactions with complex and diverse substrate structures in nature. However, the characterized LPMOs are only a small part of the sequences that have been found so far. More enzymatic and structural characterization is needed to provide more information. Structural-based mutation studies and MD simulations will bring in-depth understanding of the molecular basis of the function of LPMOs. In addition, given the complexity and structural characteristics of the substrates, it is necessary to develop more effective enzyme activity detection methods to avoid the neglect of weak enzyme activity.

\section{Abbreviations}

LPMO: Lytic polysaccharide monooxygenase; CBM: Carbohydrate-binding module; PDB: Protein data bank; NMR: Nuclear magnetic resonance; AA: Auxiliary Activity; GH: Glycoside hydrolases; MD: Molecular dynamic.

\section{Acknowledgements \\ The authors are thankful to the Guangdong Province Science and Technology Innovation Strategy Special Fund (2018B020206001); the GDAS' Special Project of Science and Technology Development (2018GDASCX-0909); and the Sci- ence and Technology Plan Project of Guangdong Province (2016A010105013, 2019B030316017); and the National Natural Science Foundation of China (31400681).}

\section{Authors' contributions}

$X Z, H Z$ developed the manuscript. XZ reviewed and corrected the manuscript for grammatical and syntax errors. $\mathrm{HZ}$ reviewed the manuscript and provided comments to enhance the quality of manuscript. Both authors read and approved the final manuscript.

\section{Funding}

This work was funded by the Guangdong Province Science and Technology Innovation Strategy Special Fund (2018B020206001); the GDAS'Special Project of Science and Technology Development (2018GDASCX-0909); and the Science and Technology Plan Project of Guangdong Province (2016A010105013, 2019B030316017); and the National Natural Science Foundation of China (31400681).

\section{Availability of data and materials \\ Not applicable.}

Ethics approval and consent to participate Not applicable.

\section{Consent for publication}

Not applicable.

\section{Competing interests}

The authors declare that they have no competing interests.

Received: 7 January 2020 Accepted: 21 February 2020

Published online: 02 March 2020

\section{References}

Aachmann FL, Sorlie M, Skjak-Braek G, Eijsink VG, Vaaje-Kolstad G (2012) NMR structure of a lytic polysaccharide monooxygenase provides insight into copper binding, protein dynamics, and substrate interactions. Proc Natl Acad Sci USA 109:18779-18784

Agger JW, Isaksen T, Varnai A, Vidal-Melgosa S, Willats WG, Ludwig R, Horn SJ, Eijsink VG, Westereng B (2014) Discovery of LPMO activity on 
hemicelluloses shows the importance of oxidative processes in plant cell wall degradation. Proc Natl Acad Sci USA 111:6287-6292

Bacik JP, Mekasha S, Forsberg Z, Kovalevsky AY, Vaaje-Kolstad G, Eijsink VGH, Nix JC, Coates L, Cuneo MJ, Unkefer CJ, Chen JC (2017) Neutron and atomic resolution $\mathrm{X}$-ray structures of a lytic polysaccharide monooxygenase reveal copper-mediated dioxygen binding and evidence for N-terminal deprotonation. Biochemistry 56:2529-2532

Beeson WT, Vu WV, Span EA, Phillips CM, Marletta MA (2015) Cellulose degradation by polysaccharide monooxygenases. Annu Rev Biochem 84:923-946

Bennati-Granier C, Garajova S, Champion C, Grisel S, Haon M, Zhou S, Fanuel M, Ropartz D, Rogniaux H, Gimbert I, Record E, Berrin JG (2015) Substrate specificity and regioselectivity of fungal AA9 lytic polysaccharide monooxygenases secreted by Podospora anserina. Biotechnol Biofuels 8:90

Bey M, Zhou S, Poidevin L, Henrissat B, Coutinho PM, Berrin JG, Sigoillot JC (2013) Cello-oligosaccharide oxidation reveals differences between two Iytic polysaccharide monooxygenases (family GH61) from Podospora anserina. Appl Environ Microbiol 79:488-496

Bissaro B, Rohr AK, Muller G, Chylenski P, Skaugen M, Forsberg Z, Horn SJ, Vaaje-Kolstad G, Eijsink VGH (2017) Oxidative cleavage of polysaccharides by monocopper enzymes depends on H2O2. Nat Chem Biol 13:1123-1128

Bissaro B, Isaksen I, Vaaje-Kolstad G, Eijsink VGH, Rohr AK (2018) How a lytic polysaccharide monooxygenase binds crystalline chitin. Biochemistry 57:1893-1906

Book AJ, Yennamalli RM, Takasuka TE, Currie CR, Phillips GN Jr, Fox BG (2014) Evolution of substrate specificity in bacterial AA10 lytic polysaccharide monooxygenases. Biotechnol Biofuels 7:109

Borisova AS, Isaksen T, Dimarogona M, Kognole AA, Mathiesen G, Varnai A, Rohr AK, Payne CM, Sorlie M, Sandgren M, Eijsink VG (2015) Structural and functional characterization of a lytic polysaccharide monooxygenase with broad substrate specificity. J Biol Chem 290:22955-22969

Cannella D, Mollers KB, Frigaard NU, Jensen PE, Bjerrum MJ, Johansen KS, Felby C (2016) Light-driven oxidation of polysaccharides by photosynthetic pigments and a metalloenzyme. Nat Commun 7:11134

Chabbert B, Habrant A, Herbaut M, Foulon L, Aguie-Beghin V, Garajova S, Grisel S, Bennati-Granier C, Gimbert-Herpoel I, Jamme F, Refregiers M, Sandt C, Berrin JG, Paes G (2017) Action of lytic polysaccharide monooxygenase on plant tissue is governed by cellular type. Sci Rep 7:17792

Chalak A, Villares A, Moreau C, Haon M, Grisel S, d'Orlando A, Herpoel-Gimbert I, Labourel A, Cathala B, Berrin JG (2019) Influence of the carbohydratebinding module on the activity of a fungal AA9 lytic polysaccharide monooxygenase on cellulosic substrates. Biotechnol Biofuels 12:206

Chaplin AK, Wilson MT, Hough MA, Svistunenko DA, Hemsworth GR, Walton PH, Vijgenboom E, Worrall JA (2016) Heterogeneity in the histidinebrace copper coordination sphere in auxiliary activity family 10 (AA10) lytic polysaccharide monooxygenases. J Biol Chem 291:12838-12850

Chen C, Chen J, Geng Z, Wang M, Liu N, Li D (2018) Regioselectivity of oxidation by a polysaccharide monooxygenase from Chaetomium thermophilum. Biotechnol Biofuels 11:155

Chiu E, Hijnen M, Bunker RD, Boudes M, Rajendran C, Aizel K, Olieric V, Schulze-Briese C, Mitsuhashi W, Young V, Ward VK, Bergoin M, Metcalf P, Coulibaly F (2015) Structural basis for the enhancement of virulence by viral spindles and their in vivo crystallization. Proc Natl Acad Sci USA 112:3973-3978

Correa TLR, Junior AT, Wolf LD, Buckeridge MS, Dos Santos LV, Murakami MT (2019) An actinobacteria lytic polysaccharide monooxygenase acts on both cellulose and xylan to boost biomass saccharification. Biotechnol Biofuels 12:117

Courtade G, Balzer S, Forsberg Z, Vaaje-Kolstad G, Eijsink VG, Aachmann FL (2015) $(1) \mathrm{H},(13) \mathrm{C},(15) \mathrm{N}$ resonance assignment of the chitin-active lytic polysaccharide monooxygenase BILPMO10A from Bacillus licheniformis. Biomol NMR Assign 9:207-210

Courtade G, Wimmer R, Rohr AK, Preims M, Felice AK, Dimarogona M, VaajeKolstad G, Sorlie M, Sandgren M, Ludwig R, Eijsink VG, Aachmann FL (2016) Interactions of a fungal lytic polysaccharide monooxygenase with beta-glucan substrates and cellobiose dehydrogenase. Proc Natl Acad Sci USA 113:5922-5927

Courtade G, Forsberg Z, Heggset EB, Eijsink VGH, Aachmann FL (2018) The carbohydrate-binding module and linker of a modular lytic polysaccharide monooxygenase promote localized cellulose oxidation. J Biol Chem 293:13006-13015

Couturier M, Ladeveze S, Sulzenbacher G, Ciano L, Fanuel M, Moreau C, Villares A, Cathala B, Chaspoul F, Frandsen KE, Labourel A, Herpoel-Gimbert I, Grisel S, Haon M, Lenfant N, Rogniaux H, Ropartz D, Davies GJ, Rosso MN, Walton PH, Henrissat B, Berrin JG (2018) Lytic xylan oxidases from wood-decay fungi unlock biomass degradation. Nat Chem Biol 14:306-310

Crouch LI, Labourel A, Walton PH, Davies GJ, Gilbert HJ (2016) The contribution of non-catalytic carbohydrate binding modules to the activity of lytic polysaccharide monooxygenases. J Biol Chem 291:7439-7449

Danneels B, Tanghe M, Joosten HJ, Gundinger T, Spadiut O, Stals I, Desmet $T$ (2017) A quantitative indicator diagram for lytic polysaccharide monooxygenases reveals the role of aromatic surface residues in HjLPMO9A regioselectivity. PLoS ONE 12:e0178446

Danneels B, Tanghe M, Desmet T (2019) Structural features on the substratebinding surface of fungal lytic polysaccharide monooxygenases determine their oxidative regioselectivity. Biotechnol J 14:e1800211

de Gouvea PF, Gerolamo LE, Bernardi AV, Pereira LMS, Uyemura SA, Dinamarco TM (2019) Lytic Polysaccharide Monooxygenase from Aspergillus fumigatus can improve enzymatic cocktail activity during sugarcane bagasse hydrolysis. Protein Pept Lett 26:377-385

Dimarogona M, Topakas E, Christakopoulos P (2013) Recalcitrant polysaccharide degradation by novel oxidative biocatalysts. Appl Microbiol Biotechnol 97:8455-8465

Eriksson KE, Pettersson B, Westermark U (1974) Oxidation: an important enzyme reaction in fungal degradation of cellulose. FEBS Lett 49:282-285

Fanuel M, Garajova S, Ropartz D, McGregor N, Brumer H, Rogniaux H, Berrin JG (2017) The Podospora anserina lytic polysaccharide monooxygenase PaLPMO9H catalyzes oxidative cleavage of diverse plant cell wall matrix glycans. Biotechnol Biofuels 10:63

Filiatrault-Chastel C, Navarro D, Haon M, Grisel S, Herpoel-Gimbert I, Chevret D, Fanuel M, Henrissat B, Heiss-Blanquet S, Margeot A, Berrin JG (2019) AA16, a new lytic polysaccharide monooxygenase family identified in fungal secretomes. Biotechnol Biofuels 12:55

Forsberg Z, Vaaje-Kolstad G, Westereng B, Bunaes AC, Stenstrom Y, MacKenzie A, Sorlie M, Horn SJ, Eijsink VG (2011) Cleavage of cellulose by a CBM33 protein. Protein Sci 20:1479-1483

Forsberg Z, Mackenzie AK, Sorlie M, Rohr AK, Helland R, Arvai AS, Vaaje-Kolstad G, Eijsink VG (2014a) Structural and functional characterization of a conserved pair of bacterial cellulose-oxidizing lytic polysaccharide monooxygenases. Proc Natl Acad Sci USA 111:8446-8451

Forsberg Z, Rohr AK, Mekasha S, Andersson KK, Eijsink VG, Vaaje-Kolstad G, Sorlie M (2014b) Comparative study of two chitin-active and two cellulose-active AA10-type lytic polysaccharide monooxygenases. Biochemistry 53:1647-1656

Forsberg Z, Nelson CE, Dalhus B, Mekasha S, Loose JS, Crouch LI, Rohr AK, Gardner JG, Eijsink VG, Vaaje-Kolstad G (2016) Structural and functional analysis of a lytic polysaccharide monooxygenase important for efficient utilization of chitin in Cellvibrio japonicus. J Biol Chem 291:7300-7312

Forsberg Z, Bissaro B, Gullesen J, Dalhus B, Vaaje-Kolstad G, Eijsink VGH (2018) Structural determinants of bacterial lytic polysaccharide monooxygenase functionality. J Biol Chem 293:1397-1412

Forsberg Z, Sørlie M, Petrović D, Courtade G, Aachmann FL, Vaaje-Kolstad G, Bissaro B, Røhr ÅK, Eijsink VG (2019) Polysaccharide degradation by lytic polysaccharide monooxygenases. Curr Opin Struct Biol 1(59):54-64

Fowler CA, Sabbadin F, Ciano L, Hemsworth GR, Elias L, Bruce N, McQueenMason S, Davies GJ, Walton PH (2019) Discovery, activity and characterisation of an AA10 lytic polysaccharide oxygenase from the shipworm symbiont Teredinibacter turnerae. Biotechnol Biofuels 12:232

Frandsen KE, Simmons TJ, Dupree P, Poulsen JC, Hemsworth GR, Ciano L, Johnston EM, Tovborg M, Johansen KS, von Freiesleben P, Marmuse L, Fort S, Cottaz S, Driguez H, Henrissat B, Lenfant N, Tuna F, Baldansuren A, Davies GJ, Lo Leggio L, Walton PH (2016) The molecular basis of polysaccharide cleavage by lytic polysaccharide monooxygenases. Nat Chem Biol 12:298-303

Frandsen KE, Poulsen JC, Tovborg M, Johansen KS, Lo Leggio L (2017) Learning from oligosaccharide soaks of crystals of an AA13 lytic polysaccharide 
monooxygenase: crystal packing, ligand binding and active-site disorder. Acta Crystallogr D Struct Biol 73:64-76

Frommhagen M, Sforza S, Westphal AH, Visser J, Hinz SW, Koetsier MJ, van Berkel WJ, Gruppen H, Kabel MA (2015) Discovery of the combined oxidative cleavage of plant xylan and cellulose by a new fungal polysaccharide monooxygenase. Biotechnol Biofuels 8:101

Frommhagen M, Koetsier MJ, Westphal AH, Visser J, Hinz SW, Vincken JP, van Berkel WJ, Kabel MA, Gruppen H (2016) Lytic polysaccharide monooxygenases from Myceliophthora thermophila C1 differ in substrate preference and reducing agent specificity. Biotechnol Biofuels 9:186

Frommhagen M, Mutte SK, Westphal AH, Koetsier MJ, Hinz SWA, Visser J, Vincken JP, Weijers D, van Berkel WJH, Gruppen H, Kabel MA (2017a) Boosting LPMO-driven lignocellulose degradation by polyphenol oxidase-activated lignin building blocks. Biotechnol Biofuels 10:121

Frommhagen M, van Erven G, Sanders M, van Berkel WJH, Kabel MA, Gruppen H (2017b) RP-UHPLC-UV-ESI-MS/MS analysis of LPMO generated C4-oxidized gluco-oligosaccharides after non-reductive labeling with 2-aminobenzamide. Carbohydr Res 448:191-199

Frommhagen M, Westphal AH, Hilgers R, Koetsier MJ, Hinz SWA, Visser J, Gruppen H, van Berkel WJH, Kabel MA (2018) Quantification of the catalytic performance of $\mathrm{C} 1$-cellulose-specific lytic polysaccharide monooxygenases. Appl Microbiol Biotechnol 102:1281-1295

Garajova S, Mathieu Y, Beccia MR, Bennati-Granier C, Biaso F, Fanuel M, Ropartz D, Guigliarelli B, Record E, Rogniaux H, Henrissat B, Berrin JG (2016) Single-domain flavoenzymes trigger lytic polysaccharide monooxygenases for oxidative degradation of cellulose. Sci Rep 6:28276

Gardner JG, Crouch L, Labourel A, Forsberg Z, Bukhman YV, Vaaje-Kolstad G, Gilbert HJ, Keating DH (2014) Systems biology defines the biological significance of redox-active proteins during cellulose degradation in an aerobic bacterium. Mol Microbiol 94(5):1121-1133

Ghatge SS, Telke AA, Waghmode TR, Lee Y, Lee KW, Oh DB, Shin HD, Kim SW (2015) Multifunctional cellulolytic auxiliary activity protein HcAA10-2 from Hahella chejuensis enhances enzymatic hydrolysis of crystalline cellulose. Appl Microbiol Biotechnol 99:3041-3055

Gregory RC, Hemsworth GR, Turkenburg JP, Hart SJ, Walton PH, Davies GJ (2016) Activity, stability and 3-D structure of the Cu(ii) form of a chitinactive lytic polysaccharide monooxygenase from Bacillus amyloliquefaciens. Dalton Trans 45:16904-16912

Gudmundsson M, Kim S, Wu M, Ishida T, Momeni MH, Vaaje-Kolstad G, Lundberg D, Royant A, Stahlberg J, Eijsink VG, Beckham GT, Sandgren M (2014) Structural and electronic snapshots during the transition from a $\mathrm{Cu}(\mathrm{II})$ to $\mathrm{Cu}(\mathrm{I})$ metal center of a lytic polysaccharide monooxygenase by X-ray photoreduction. J Biol Chem 289:18782-18792

Gusakov AV, Bulakhov AG, Demin IN, Sinitsyn AP (2017) Monitoring of reactions catalyzed by lytic polysaccharide monooxygenases using highlysensitive fluorimetric assay of the oxygen consumption rate. Carbohydr Res 452:156-161

Hansson H, Karkehabadi S, Mikkelsen N, Douglas NR, Kim S, Lam A, Kaper T, Kelemen B, Meier KK, Jones SM, Solomon El, Sandgren M (2017) Highresolution structure of a lytic polysaccharide monooxygenase from Hypocrea jecorina reveals a predicted linker as an integral part of the catalytic domain. J Biol Chem 292:19099-19109

Harris PV, Welner D, McFarland KC, Re E, Navarro Poulsen JC, Brown K, Salbo R, Ding H, Vlasenko E, Merino S, Xu F, Cherry J, Larsen S, Lo Leggio L (2010) Stimulation of lignocellulosic biomass hydrolysis by proteins of glycoside hydrolase family 61: structure and function of a large, enigmatic family. Biochemistry 49:3305-3316

Hegnar OA, Petrovic DM, Bissaro B, Alfredsen G, Várnai A, Eijsink VG (2019) $\mathrm{pH}$-dependent relationship between catalytic activity and hydrogen peroxide production shown via characterization of a lytic polysaccharide monooxygenase from Gloeophyllum trabeum. Appl Environ Microbiol 85(5):e02612-18

Hemsworth GR, Davies GJ, Walton PH (2013a) Recent insights into coppercontaining lytic polysaccharide mono-oxygenases. Curr Opin Struct Biol 23:660-668

Hemsworth GR, Taylor EJ, Kim RQ, Gregory RC, Lewis SJ, Turkenburg JP, Parkin A, Davies GJ, Walton PH (2013b) The copper active site of CBM33 polysaccharide oxygenases. J Am Chem Soc 135:6069-6077

Hemsworth GR, Henrissat B, Davies GJ, Walton PH (2014) Discovery and characterization of a new family of lytic polysaccharide monooxygenases. Nat Chem Biol 10:122-126
Hemsworth GR, Johnston EM, Davies GJ, Walton PH (2015) Lytic polysaccharide monooxygenases in biomass conversion. Trends Biotechnol 33:747-761

Huttner S, Varnai A, Petrovic DM, Bach CX, Kim Anh DT, Thanh VN, Eijsink VGH, Larsbrink J, Olsson L (2019) Specific xylan activity revealed for AA9 lytic polysaccharide monooxygenases of the thermophilic fungus Malbranchea cinnamomea by functional characterization. Appl Environ Microbiol. https://doi.org/10.1128/AEM.01408-19

Isaksen T, Westereng B, Aachmann FL, Agger JW, Kracher D, Kittl R, Ludwig R, Haltrich D, Eijsink VG, Horn SJ (2014) A C4-oxidizing lytic polysaccharide monooxygenase cleaving both cellulose and cello-oligosaccharides. J Biol Chem 289:2632-2642

Jagadeeswaran G, Gainey L, Prade R, Mort AJ (2016) A family of AA9 Iytic polysaccharide monooxygenases in Aspergillus nidulans is differentially regulated by multiple substrates and at least one is active on cellulose and xyloglucan. Appl Microbiol Biotechnol 100:4535-4547

Jagadeeswaran G, Gainey L, Mort AJ (2018) An AA9-LPMO containing a CBM1 domain in Aspergillus nidulans is active on cellulose and cleaves cellooligosaccharides. AMB Express 8:171

Jensen MS, Klinkenberg G, Bissaro B, Chylenski P, Vaaje-Kolstad G, Kvitvang HF, Naerdal GK, Sletta H, Forsberg Z, Eijsink VGH (2019) Engineering chitinolytic activity into a cellulose-active lytic polysaccharide monooxygenase provides insights into substrate specificity. J Biol Chem 294:19349-19364

Kadowaki MA, Varnai A, Jameson JK, Leite AE, Costa-Filho AJ, Kumagai PS, Prade RA, Polikarpov I, Eijsink VG (2018) Functional characterization of a lytic polysaccharide monooxygenase from the thermophilic fungus Myceliophthora thermophila. PLOS ONE 13(8):e0202148

Karkehabadi S, Hansson H, Kim S, Piens K, Mitchinson C, Sandgren M (2008) The first structure of a glycoside hydrolase family 61 member, Cel61B from Hypocrea jecorina, at 1.6 A resolution. J Mol Biol 383:144-154

Karnaouri A, Muraleedharan MN, Dimarogona M, Topakas E, Rova U, Sandgren M, Christakopoulos P (2017) Recombinant expression of thermostable processive MtEG5 endoglucanase and its synergism with MtLPMO from Myceliophthora thermophila during the hydrolysis of lignocellulosic substrates. Biotechnol Biofuels 10:126

Kim IJ, Seo N, An HJ, Kim JH, Harris PV, Kim KH (2017) Type-dependent action modes of TtAA9E and TaAA9A acting on cellulose and differently pretreated lignocellulosic substrates. Biotechnol Biofuels 10:46

Kitaoku Y, Courtade G, Petrovic DM, Fukamizo T, Eijsink VGH, Aachmann FL (2018) Resonance assignments for the apo-form of the cellulose-active lytic polysaccharide monooxygenase TaLPMO9A. Biomol NMR Assign 12:357-361

Kittl R, Kracher D, Burgstaller D, Haltrich D, Ludwig R (2012) Production of four Neurospora crassa lytic polysaccharide monooxygenases in Pichia pastoris monitored by a fluorimetric assay. Biotechnol Biofuels 5:79

Kjaergaard CH, Qayyum MF, Wong SD, Xu F, Hemsworth GR, Walton DJ, Young NA, Davies GJ, Walton PH, Johansen KS, Hodgson KO, Hedman B, Solomon El (2014) Spectroscopic and computational insight into the activation of $\mathrm{O}_{2}$ by the mononuclear $\mathrm{Cu}$ center in polysaccharide monooxygenases. Proc Natl Acad Sci USA 111:8797-8802

Kojima Y, Varnai A, Ishida T, Sunagawa N, Petrovic DM, Igarashi K, Jellison J, Goodell B, Alfredsen G, Westereng B, Eijsink VG, Yoshida M (2016) A Iytic polysaccharide monooxygenase with broad xyloglucan specificity from the brown-rot fungus Gloeophyllum trabeum and its action on cellulose-xyloglucan complexes. Appl Environ Microbiol 82:6557-6572

Kracher D, Scheiblbrandner S, Felice AK, BresImayr E, Preims M, Ludwicka K, Haltrich D, Eijsink VG, Ludwig R (2016) Extracellular electron transfer systems fuel cellulose oxidative degradation. Science 352:1098-1101

Kracher D, Andlar M, Furtmuller PG, Ludwig R (2018) Active-site copper reduction promotes substrate binding of fungal lytic polysaccharide monooxygenase and reduces stability. J Biol Chem 293:1676-1687

Kruer-Zerhusen N, Alahuhta M, Lunin VV, Himmel ME, Bomble YJ, Wilson DB (2017) Structure of a Thermobifida fusca lytic polysaccharide monooxygenase and mutagenesis of key residues. Biotechnol Biofuels 10:243

Ladeveze S, Haon M, Villares A, Cathala B, Grisel S, Herpoel-Gimbert I, Henrissat B, Berrin JG (2017) The yeast Geotrichum candidum encodes functional Iytic polysaccharide monooxygenases. Biotechnol Biofuels 10:215

Laurent CV, Sun P, Scheiblbrandner S, Csarman F, Cannazza P, Frommhagen M, van Berkel WJ, Oostenbrink C, Kabel MA, Ludwig R (2019) Influence of 
Iytic polysaccharide monooxygenase active site segments on activity and affinity. Int J Mol Sci 20(24):6219

Li X, Beeson WT IV, Phillips CM, Marletta MA, Cate JH (2012) Structural basis for substrate targeting and catalysis by fungal polysaccharide monooxygenases. Structure 20(6):1051-1061

Liu B, Olson A, Wu M, Broberg A, Sandgren M (2017) Biochemical studies of two lytic polysaccharide monooxygenases from the white-rot fungus Heterobasidion irregulare and their roles in lignocellulose degradation. PLOS ONE 12:e0189479

Liu B, Kognole AA, Wu M, Westereng B, Crowley MF, Kim S, Dimarogona M, Payne CM, Sandgren M (2018) Structural and molecular dynamics studies of a C1-oxidizing lytic polysaccharide monooxygenase from Heterobasidion irregulare reveal amino acids important for substrate recognition. FEBS J 285:2225-2242

Lo Leggio L, Simmons TJ, Poulsen JC, Frandsen KE, Hemsworth GR, Stringer MA, von Freiesleben P, Tovborg M, Johansen KS, De Maria L, Harris PV, Soong CL, Dupree P, Tryfona T, Lenfant N, Henrissat B, Davies GJ, Walton PH (2015) Structure and boosting activity of a starch-degrading lytic polysaccharide monooxygenase. Nat Commun 6:5961

Lo Leggio L, Weihe CD, Poulsen JN, Sweeney M, Rasmussen F, Lin J, De Maria L, Wogulis M (2018) Structure of a lytic polysaccharide monooxygenase from Aspergillus fumigatus and an engineered thermostable variant. Carbohydr Res 469:55-59

Loose JS, Forsberg Z, Fraaije MW, Eijsink VG, Vaaje-Kolstad G (2014) A rapid quantitative activity assay shows that the Vibrio cholerae colonization factor GbpA is an active lytic polysaccharide monooxygenase. FEBS Lett 588:3435-3440

Manjeet K, Purushotham P, Neeraja C, Podile AR (2013) Bacterial chitin binding proteins show differential substrate binding and synergy with chitinases. Microbiol Res 168:461-468

Manjeet K, Madhuprakash J, Mormann M, Moerschbacher BM, Podile AR (2019) A carbohydrate binding module-5 is essential for oxidative cleavage of chitin by a multi-modular lytic polysaccharide monooxygenase from Bacillus thuringiensis serovar kurstaki. Int J Biol Macromo 127:649-656

Mekasha S, Forsberg Z, Dalhus B, Bacik JP, Choudhary S, Schmidt-Dannert C, Vaaje-Kolstad G, Eijsink VG (2016) Structural and functional characterization of a small chitin-active lytic polysaccharide monooxygenase domain of a multi-modular chitinase from Jonesia denitrificans. FEBS Lett 590:34-42

Mollers KB, Mikkelsen H, Simonsen TI, Cannella D, Johansen KS, Bjerrum MJ, Felby C (2017) On the formation and role of reactive oxygen species in light-driven LPMO oxidation of phosphoric acid swollen cellulose. Carbohydr Res 448:182-186

Muller G, Varnai A, Johansen KS, Eijsink VG, Horn SJ (2015) Harnessing the potential of LPMO-containing cellulase cocktails poses new demands on processing conditions. Biotechnol Biofuels 8:187

Mutahir Z, Mekasha S, Loose JSM, Abbas F, Vaaje-Kolstad G, Eijsink VGH, Forsberg Z (2018) Characterization and synergistic action of a tetra-modular lytic polysaccharide monooxygenase from Bacillus cereus. FEBS Lett 592:2562-2571

Nakagawa YS, Kudo M, Loose JS, Ishikawa T, Totani K, Eijsink VG, Vaaje-Kolstad G (2015) A small lytic polysaccharide monooxygenase from Streptomyces griseus targeting alpha- and beta-chitin. FEBS J 282:1065-1079

Nekiunaite L, Isaksen T, Vaaje-Kolstad G, Abou Hachem M (2016a) Fungal Iytic polysaccharide monooxygenases bind starch and beta-cyclodextrin similarly to amylolytic hydrolases. FEBS Lett 590:2737-2747

Nekiunaite L, Petrovic DM, Westereng B, Vaaje-Kolstad G, Hachem MA, Varnai A, Eijsink VG (2016b) FgLPMO9A from Fusarium graminearum cleaves xyloglucan independently of the backbone substitution pattern. FEBS Lett 590:3346-3356

Paspaliari DK, Loose JS, Larsen MH, Vaaje-Kolstad G (2015) Listeria monocytogenes has a functional chitinolytic system and an active lytic polysaccharide monooxygenase. FEBS J 282:921-936

Patel I, Kracher D, Ma S, Garajova S, Haon M, Faulds CB, Berrin JG, Ludwig R, Record E (2016) Salt-responsive lytic polysaccharide monooxygenases from the mangrove fungus Pestalotiopsis sp. NCi6. Biotechnol Biofuels 9:108

Petrovic DM, Bissaro B, Chylenski P, Skaugen M, Sorlie M, Jensen MS, Aachmann FL, Courtade G, Varnai A, Eijsink VGH (2018) Methylation of the
$\mathrm{N}$-terminal histidine protects a lytic polysaccharide monooxygenase from auto-oxidative inactivation. Protein Sci 27:1636-1650

Petrovic DM, Varnai A, Dimarogona M, Mathiesen G, Sandgren M, Westereng B, Eijsink VGH (2019) Comparison of three seemingly similar lytic polysaccharide monooxygenases from Neurospora crassa suggests different roles in plant biomass degradation. J Biol Chem 294:15068-15081

Quinlan RJ, Sweeney MD, Lo Leggio L, Otten H, Poulsen JC, Johansen KS, Krogh KB, Jorgensen Cl, Tovborg M, Anthonsen A, Tryfona T, Walter CP, Dupree P, Xu F, Davies GJ, Walton PH (2011) Insights into the oxidative degradation of cellulose by a copper metalloenzyme that exploits biomass components. Proc Natl Acad Sci USA 108:15079-15084

Reese ET, Siu RG, Levinson HS (1950) The biological degradation of soluble cellulose derivatives and its relationship to the mechanism of cellulose hydrolysis. J Bacteriol 59:485-497

Russo DA, Zedler JAZ, Wittmann DN, Mollers B, Singh RK, Batth TS, van Oort B, Olsen JV, Bjerrum MJ, Jensen PE (2019) Expression and secretion of a lytic polysaccharide monooxygenase by a fast-growing cyanobacterium. Biotechnol Biofuels 12:74

Sabbadin F, Hemsworth GR, Ciano L, Henrissat B, Dupree P, Tryfona T, Marques RDS, Sweeney ST, Besser K, Elias L, Pesante G, LiY, Dowle AA, Bates R, Gomez LD, Simister R, Davies GJ, Walton PH, Bruce NC, McQueenMason SJ (2018) An ancient family of lytic polysaccharide monooxygenases with roles in arthropod development and biomass digestion. Nat Commun 9:756

Shukla AK, Upadhyay SK, Mishra M, Saurabh S, Singh R, Singh H, Thakur N, Rai P, Pandey P, Hans AL, Srivastava S, Rajapure V, Yadav SK, Singh MK, Kumar J, Chandrashekar K, Verma PC, Singh AP, Nair KN, Bhadauria S, Wahajuddin M, Singh S, Sharma S, Omkar, Upadhyay RS, Ranade SA, Tuli R, Singh PK (2016) Expression of an insecticidal fern protein in cotton protects against whitefly. Nat Biotechnol 34:1046-1051

Simmons TJ, Frandsen KEH, Ciano L, Tryfona T, Lenfant N, Poulsen JC, Wilson LFL, Tandrup T, Tovborg M, Schnorr K, Johansen KS, Henrissat B, Walton PH, Lo Leggio L, Dupree P (2017) Structural and electronic determinants of lytic polysaccharide monooxygenase reactivity on polysaccharide substrates. Nat Commun 8:1064

Singh RK, Blossom BM, Russo DA, Singh R, Weihe H, Andersen NH, Tiwari MK, Jensen PE, Felby C, Bjerrum MJ (2020) Detection and characterization of a novel copper-dependent intermediate in a lytic polysaccharide monooxygenase. Eur J 26(2):454-463

Span EA, Marletta MA (2015) The framework of polysaccharide monooxygenase structure and chemistry. Curr Opin Struct Biol 35:93-99

Span EA, Suess DLM, Deller MC, Britt RD, Marletta MA (2017) The role of the secondary coordination sphere in a fungal polysaccharide monooxygenase. ACS Chem Biol 12:1095-1103

Tan TC, Kracher D, Gandini R, Sygmund C, Kittl R, Haltrich D, Hallberg BM, Ludwig R, Divne C (2015) Structural basis for cellobiose dehydrogenase action during oxidative cellulose degradation. Nat Commun 6:7542

Tandrup T, Frandsen KEH, Johansen KS, Berrin JG, Lo Leggio L (2018) Recent insights into lytic polysaccharide monooxygenases (LPMOs). Biochem Soc Trans 46:1431-1447

Tanghe M, Danneels B, Camattari A, Glieder A, Vandenberghe I, Devreese B, Stals I, Desmet T (2015) Recombinant Expression of Trichoderma reesei Cel61 A in Pichia pastoris: optimizing Yield and N-terminal Processing. Mol Biotechnol 57:1010-1017

Vaaje-Kolstad G, Horn SJ, van Aalten DM, Synstad B, Eijsink VG (2005a) The non-catalytic chitin-binding protein CBP21 from Serratia marcescens is essential for chitin degradation. J Biol Chem 280:28492-28497

Vaaje-Kolstad G, Houston DR, Riemen AH, Eijsink VG, van Aalten DM (2005b) Crystal structure and binding properties of the Serratia marcescens chitin-binding protein CBP21. J Biol Chem 280:11313-11319

Vaaje-Kolstad G, Westereng B, Horn SJ, Liu Z, Zhai H, Sørlie M, Eijsink VG (2010) An oxidative enzyme boosting the enzymatic conversion of recalcitrant polysaccharides. Science 330(6001):219-222

Vaaje-Kolstad G, Bohle LA, Gaseidnes S, Dalhus B, Bjoras M, Mathiesen G, Eijsink VG (2012) Characterization of the chitinolytic machinery of Enterococcus faecalis V583 and high-resolution structure of its oxidative CBM33 enzyme. J Mol Biol 416:239-254 
Vaaje-Kolstad G, Forsberg Z, Loose JS, Bissaro B, Eijsink VG (2017) Structural diversity of lytic polysaccharide monooxygenases. Curr Opin Struct Biol 44:67-76

Valenzuela SV, Ferreres G, Margalef G, Pastor FIJ (2017) Fast purification method of functional LPMOs from Streptomyces ambofaciens by affinity adsorption. Carbohydr Res 448:205-211

Várnai A, Umezawa K, Yoshida M, Eijsink VG (2018) The pyrroloquinolinequinone-dependent pyranose dehydrogenase from Coprinopsis cinerea drives lytic polysaccharide monooxygenase action. Appl Environ Microbiol 84(11):e00156-18

Villares A, Moreau C, Bennati-Granier C, Garajova S, Foucat L, Falourd X, Saake B, Berrin JG, Cathala B (2017) Lytic polysaccharide monooxygenases disrupt the cellulose fibers structure. Sci Rep 7:40262

Vu WV, Beeson WT, Phillips CM, Cate JH, Marletta MA (2014a) Determinants of regioselective hydroxylation in the fungal polysaccharide monooxygenases. J Am Chem Soc 136:562-565

Vu V, Beeson WT, Span EA, Farquhar ER, Marletta MA (2014b) A family of starch-active polysaccharide monooxygenases. Proc Natl Acad Sci USA 111:13822-13827

Vu W, Hangasky JA, Detomasi TC, Henry SJW, Ngo ST, Span EA, Marletta MA (2019) Substrate selectivity in starch polysaccharide monooxygenases. J Biol Chem 294:12157-12166

Vuong TV, Liu B, Sandgren M, Master ER (2017) Microplate-based detection of lytic polysaccharide monooxygenase activity by fluorescence-labeling of insoluble oxidized products. Biomacromolecules 18:610-616

Walton PH, Davies GJ (2016) On the catalytic mechanisms of lytic polysaccharide monooxygenases. Curr Opin Chem Biol 31:195-207

Wang D, Li J, Wong ACY, Aachmann FL, Hsieh YSY (2018) A colorimetric assay to rapidly determine the activities of lytic polysaccharide monooxygenases. Biotechnol Biofuels 11:215

Westereng B, Ishida T, Vaaje-Kolstad G, Wu M, Eijsink VG, Igarashi K, Samejima M, Stahlberg J, Horn SJ, Sandgren M (2011) The putative endoglucanase PcGH61D from Phanerochaete chrysosporium is a metal-dependent oxidative enzyme that cleaves cellulose. PLoS ONE 6:e27807

Westereng B, Agger JW, Horn SJ, Vaaje-Kolstad G, Aachmann FL, Stenstrom YH, Eijsink VG (2013) Efficient separation of oxidized cello-oligosaccharides generated by cellulose degrading lytic polysaccharide monooxygenases. J Chromatogr A 1271:144-152

Westereng B, Cannella D, Wittrup Agger J, Jorgensen H, Larsen Andersen M, Eijsink VG, Felby C (2015) Enzymatic cellulose oxidation is linked to lignin by long-range electron transfer. Sci Rep 5:18561
Westereng B, Arntzen MO, Aachmann FL, Varnai A, Eijsink VG, Agger JW (2016) Simultaneous analysis of $\mathrm{C} 1$ and $C 4$ oxidized oligosaccharides, the products of lytic polysaccharide monooxygenases acting on cellulose. $J$ Chromatogr A 1445:46-54

Wong E, Vaaje-Kolstad G, Ghosh A, Hurtado-Guerrero R, Konarev PV, Ibrahim AF, Svergun DI, Eijsink VG, Chatterjee NS, van Aalten DM (2012) The Vibrio cholerae colonization factor GbpA possesses a modular structure that governs binding to different host surfaces. PLoS Pathog 8:e1002373

Wu M, Beckham GT, Larsson AM, Ishida T, Kim S, Payne CM, Himmel ME, Crowley MF, Horn SJ, Westereng B, Igarashi K, Samejima M, Stahlberg J, Eijsink VG, Sandgren M (2013) Crystal structure and computational characterization of the lytic polysaccharide monooxygenase GH61D from the Basidiomycota fungus Phanerochaete chrysosporium. J Biol Chem 288:12828-12839

Yadav SK, Archana, Singh R, Singh PK, Vasudev PG (2019) Insecticidal fern protein Tma12 is possibly a lytic polysaccharide monooxygenase. Planta 249(6):1987-1996

Zhang H, Zhao Y, Cao H, Mou G, Yin H (2015) Expression and characterization of a lytic polysaccharide monooxygenase from Bacillus thuringiensis. Int J Biol Macromol 79:72-75

Zhang R, Liu Y, Zhang Y, Feng D, Hou S, Guo W, Niu K, Jiang Y, Han L, Sindhu $L$, Fang $X$ (2019) Identification of a thermostable fungal lytic polysaccharide monooxygenase and evaluation of its effect on lignocellulosic degradation. Appl Microbiol Biotechnol 103:5739-5750

Zhou H, Li T, Yu Z, Ju J, Zhang H, Tan H, Li K, Yin H (2019a) A lytic polysaccharide monooxygenase from Myceliophthora thermophila and its synergism with cellobiohydrolases in cellulose hydrolysis. Int J Biol Macromol 139:570-576

Zhou X, Qi X, Huang H, Zhu H (2019b) Sequence and structural analysis of AA9 and AA10 LPMOs: an insight into the basis of substrate specificity and regioselectivity. Int J Mol Sci 20(18):4594

\section{Publisher's Note}

Springer Nature remains neutral with regard to jurisdictional claims in published maps and institutional affiliations.

\section{Submit your manuscript to a SpringerOpen ${ }^{\odot}$ journal and benefit from:}

- Convenient online submission

- Rigorous peer review

- Open access: articles freely available online

- High visibility within the field

- Retaining the copyright to your article

Submit your next manuscript at $\boldsymbol{\nabla}$ springeropen.com 